\title{
Seasonal growth, molt, and egg production rates of Nyctiphanes simplex (Crustacea: Euphausiacea) juveniles and adults in the Gulf of California
}

\author{
Jaime Gómez-Gutiérrez ${ }^{1, *}$, Samuel Martínez-Gómez ${ }^{1}$, Carlos J. Robinson² \\ ${ }^{1}$ Departamento de Plancton y Ecología Marina, Centro Interdisciplinario de Ciencias Marinas, Instituto Politécnico Nacional, \\ Av. IPN s/n, Col. Playa Palo de Santa Rita, La Paz, Baja California Sur, 23096, Mexico \\ ${ }^{2}$ Laboratorio de Ecología de Pesquerías, Instituto de Ciencias del Mar y Limnología, Universidad Nacional Autónoma de México, \\ AP 70-305, México, Distrito Federal 04510, Mexico
}

\begin{abstract}
Seasonal distribution of biomass and somatic growth, molt, and egg production rates of Nyctiphanes simplex were estimated in the Gulf of California (November 2005, January 2007 and July 2007) and associated with 12 environmental variables to define the conditions in which the higher biomass production rates occur. Daily growth rates, estimated from shipboard incubations, indicated that $N$. simplex did not grow or decreased in size in all the seasons, with higher proportions of animals in these 2 growth categories in July (21 and $52 \%$, respectively) than in January ( 7 and $43 \%$ ) and November (35 and $12 \%$ ). Thus, the proportion of individuals that grew was higher in November (53\%) and January $(50 \%)$ than in July $(27 \%)$. Mean juvenile and adult intermolt period (IMP) based on direct measurements was $5 \mathrm{~d}$ in January (range: 3 to $7 \mathrm{~d}$ ), $3.8 \mathrm{~d}$ in July ( 2 to $8 \mathrm{~d}$ ) and $4.4 \mathrm{~d}$ ( 3 to $7 \mathrm{~d}$ ) for September to October 2010 (used as proxy for November, since not enough IMP data were available for that month). Calculations based on the inverse molting rate method estimated higher mean IMP $(6.7 \mathrm{~d}$; range 4 to $60 \mathrm{~d})$. N. simplex mean $( \pm \mathrm{SD})$ juvenile and adult daily total biomass production rate was $0.16 \pm 0.13 \mathrm{mg} \mathrm{DW} \mathrm{m}^{-3} \mathrm{~d}^{-1}$ ( $\mathrm{DW}=$ dry weight) and mean annual integrated production was $71 \pm 58 \mathrm{mg} \mathrm{DW} \mathrm{m}^{-3} \mathrm{yr}^{-1}$. The greatest contribution to $N$. simplex biomass production was through somatic growth $(46 \%)$, followed by molts $(32 \%)$ and eggs $(22 \%) . N$. simplex had high biomass and biomass production rates mostly in regions with $<100 \mathrm{~m}$ seafloor depth, in the northeast Gulf during November, northwest during January, and along the central east coast of the Gulf during July, associated with upwelling conditions that geographically change with winter anticyclonic and summer cyclonic surface circulation. Thus, numerous predators that energetically depend on this prey must seasonally change their distribution pattern to detect the spatially variable centers of $N$. simplex biomass production in the Gulf of California.
\end{abstract}

KEY WORDS: Nyctiphanes simplex - Biomass production - Body growth - Molts - Eggs · Gulf of California

Resale or republication not permitted without written consent of the publisher

\section{INTRODUCTION}

Nyctiphanes simplex dominates the euphausiid abundance (60 to $90 \%$ ) throughout the year along both coasts of the Baja California peninsula, typically peaking in abundance during spring (Brinton \& Townsend 1980, Lavaniegos 1995). N. simplex is a subtropical neritic krill species that lays its eggs in an ovigerous sac of up to $19 \mathrm{~mm}$ total length (GómezGutiérrez et al. 2010a) and has an estimated life span ranging from 8 mo to $1 \mathrm{yr}$ (Lavaniegos 1992). We previously collected relatively rare, large $N$. simplex individuals (20 to $24 \mathrm{~mm}$ total length) in the Gulf of California (J. Gómez-Gutiérrez unpubl. data). N. 
simplex forms dense swarms that attract multiple predators such as zooplanktophagous fishes, sea birds, and sea mammals (Brinton \& Townsend 1980, Gendron 1992), and it plays a relevant trophic role as an abundant omnivorous grazer consuming phytodetritus $(88.6 \%)$, crustaceans $(9.1 \%)$, radiolarians $(1 \%)$, and tintinnids (1.3\%) (Kanaeva \& Pavlov 1976). Using proportions of this trophic spectrum in an Ecopath subroutine (Pauly et al. 2000), we suggest that $N$. simplex occupies a 2.1 trophic level. The highest densities of $N$. simplex occur in the neritic zone of the northern and central part of the Gulf of California, decreasing in abundance toward the south (Brinton \& Townsend 1980). The population reaches peak abundance and maximum reproductive activities - indicated by ovigerous females and males with spermatophores-between January and April, and lowest abundance levels occur between July and October (Brinton \& Townsend 1980).

Multiple studies have estimated Nyctiphanes simplex biomass production rates along the west coast of Baja California peninsula (Lavaniegos 1995, GómezGutiérrez et al. 1996, De Silva-Dávila et al. 2002) and in La Paz Bay (southwestern Gulf of California; De Silva-Dávila \& Palomares-García 1998). However, all these studies estimated $N$. simplex productivity using only preserved specimens without any direct measurements of vital rates. The present study is the first estimation of $N$. simplex biomass production using shipboard experimental vital rate measurements, and the first biomass production estimation for any zooplankton species in the Gulf of California, excluding the estimation of somatic growth production of $N$. simplex in La Paz Bay (De Silva-Dávila \& PalomaresGarcía 1998) and several measurements of copepod egg productions in the Concepción and La Paz Bays (Palomares-García et al. 2006).

The Gulf of California is a subtropical ecosystem with pronounced seasonal changes in physical, chemical, and biological oceanographic conditions that respond directly to the influence of currents of the Pacific Ocean, patterns and intensity of the winds, and the rate of heat exchange between the atmosphere and the ocean (Lavin \& Marinone 2003). From December to May, intense and sustained upwelling conditions occur along the east coast of the Gulf, driven by northwest winds. From July to October, upwelling conditions still occur along the east coast of the Gulf-albeit with considerably less intensityassociated with southeast winds. The annual net vertically integrated primary production is divided into 3 periods: (1) cold season (December to May) with primary production values ranging from 1.16 to $1.91 \mathrm{~g} \mathrm{C}$ $\mathrm{m}^{-2} \mathrm{~d}^{-1}$, (2) warm season (July to October) with values 4 times lower than in winter, ranging from 0.39 to $0.49 \mathrm{~g} \mathrm{C} \mathrm{m}^{-2} \mathrm{~d}^{-1}$, and (3) 2 brief transitional periods (typically occurring in June and November) with intermediate primary productivity values (Hidalgo-Gonzalez \& Alvarez-Borrego 2004). These pronounced differences in seasonal phytoplankton productivities likely influence the zooplankton biomass and secondary production rates in the Gulf of California.

Along the west coast of Baja California peninsula Nyctiphanes simplex has an estimated productivity of $1736 \mathrm{mg} \mathrm{m}^{-2} \mathrm{yr}^{-1}$ (based only on preserved specimens) where body growth rates contribute most $(74.7 \%)$ to its biomass productivity, followed by molts $(23.4 \%)$ and egg production rates $(1.9 \%)$ (Lavaniegos 1995). Preliminary measurements of the intermolt period (IMP), gonad development, interbrood period (IBP), brood sizes (BS), and reproductive effort (RE) of live $N$. simplex during shipboard experiments suggested that $N$. simplex may invest more energy in egg production than previously thought (GómezGutiérrez \& Robinson 2005, Gómez-Gutiérrez et al. $2010 a, b)$. These vital rate observations are important because precise biomass and secondary productivity estimations in the Gulf of California may conceptually modify trophic and ecological models of krill predators such as the jumbo squid Dosidicus gigas (Rosas-Luis et al. 2008).

Our goal was to estimate the seasonal Nyctiphanes simplex distribution of biomass and total biomass production (somatic growth, molt, and egg production rates) by measuring its vital rates (daily growth rates [DGR], IMP, IBP, and BS) under shipboard laboratory conditions. We also aimed to define the environmental conditions in which the $N$. simplex highest and lowest biomass production rates occur in the Gulf of California by determining associations between biomass and total biomass production with multiple environmental variables measured in situ.

\section{MATERIALS AND METHODS}

Nyctiphanes simplex biomass and biomass production rates of juveniles and adults were estimated from specimens collected in the northern and central part of the Gulf of California aboard the R/V 'El Puma' from 16 November to 3 December 2005, 12 to 31 January 2007, and 17 July to 3 August 2007 (Fig. 1). Additional shipboard vital rate measurements were obtained during 3 cruises carried out from 11 to 25 March 2010, 25 September to 9 October 2010, and 24 November to 11 December 2011 (see Table 1). 


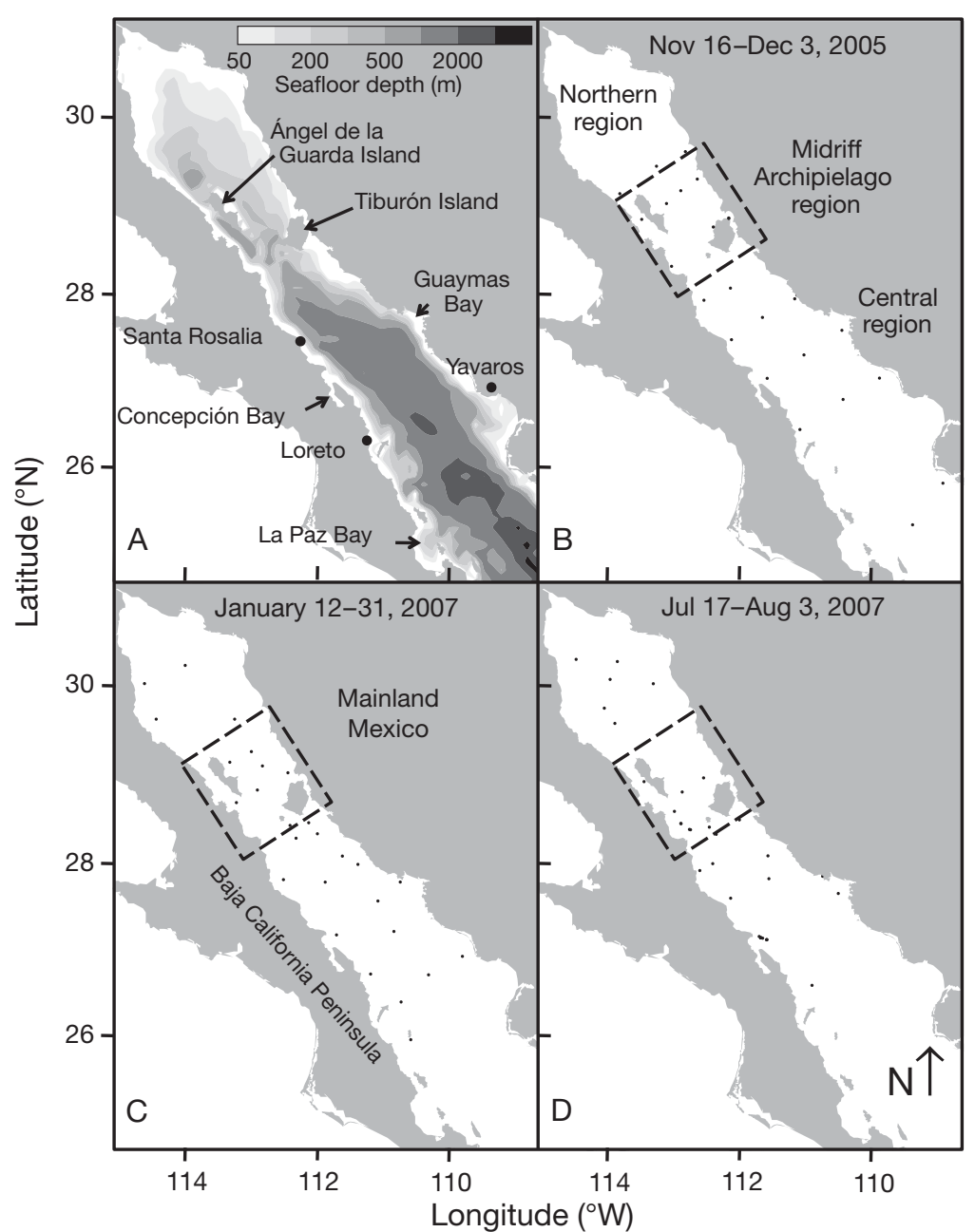

Fig. 1. Study area in the Gulf of California, Mexico. (A) Bathymetry. Oceanographic stations occupied during (B) November 2005, (C) January 2007, and (D) July 2007. Locations of stations used in 2010 and 2011 are given in Table 1

\section{Environmental variables}

Temperature, density, and salinity profiles were determined using a General Oceanics Mark II CTD sensor during November 2005 and January 2007. In July 2007, a CTD Seabird SB09 equipped with an oxymeter was used to measure dissolved oxygen concentration. Water samples were obtained at discrete water column depths $(0,5,10,25,50,75$, and $100 \mathrm{~m}$ ) with 201 Niskin bottles to measure temperature $\left({ }^{\circ} \mathrm{C}\right)$, dissolved oxygen concentration $\left(\mathrm{ml} \mathrm{O}_{2} \mathrm{l}^{-1}\right)$, and oxygen saturation (\%) with a multi-sensor YSI 556 MPS. At each sampling depth, 21 seawater was GF/F filtered ( $0.7 \mu \mathrm{m}$ pore size) and immediately frozen in liquid nitrogen for subsequent analysis of chlorophyll a (chl a) concentration. We quantified 11 phytoplankton pigments using HPLC (Vidussi et al.
1996), accounting for differences in the pigment response factor (Mantoura \& Repeta 1997) and using commercial pigment standards (International Atomic Energy Agency for ${ }^{14} \mathrm{C}$ stable isotope determinations). The phytoplankton pigments were identified based on their retention times and spectral characteristics. Several of these accessory pigments were useful proxies of specific phytoplankton groups; for example, peridinin is an indicator of dinoflagellates, fucoxanthin of diatoms, alloxanthin of cryptophytes, and chl $a$ is a proxy of the whole phytoplankton community biomass (Palomares-García et al. 2006). Seasonal variability of sea surface temperature (SST) and chl a was analyzed using mean weekly satellite imagery from MODIS (Moderate Resolution Imaging Spectralradiometer aboard the Terra satellite, $9 \mathrm{~km}$ resolution; http://oceandata.sci. gsfc.nasa.gov/MODISA/Mapped/8Day/ $9 \mathrm{~km} / \mathrm{SST} /$ ) and integrated SeaWiFS surface chl a concentrations (4 km resolution; http://oceandata.sci.gsfc.nasa.gov/ SeaWiFS/Mapped/8Day/9km/) respectively, for the sampling period of each oceanographic cruise.

\section{Shipboard Nyctiphanes simplex vital rate experiments}

Nyctiphanes simplex specimens were collected with a $1 \mathrm{~m}$ mouth diameter zooplankton net that was $5 \mathrm{~m}$ long and constructed of black $300 \mu \mathrm{m}$ mesh equipped with a nonfiltering cod end (0.22 $\mathrm{m}$ diameter and $0.70 \mathrm{~m}$ long). This net was equipped with an underwater lamp (Ikelite, Provideo-lite II system, $50 \mathrm{~W}$ ) to attract euphausiids (Gómez-Gutiérrez \& Robinson 2006). Live zooplankton was collected by lowering the net for approximately $10 \mathrm{~min}$ to the depth where the echosounder (Simrad EY-500, $120 \mathrm{kHz}$ frequency split beam) detected large zooplankton densities while the ship was drifting. The healthy euphausiids (transparent, with active and agile swimming movements, and without injured body parts) were randomly collected with a plastic spoon. Each $N$. simplex individual was incubated in a transparent plastic polycarbonate bottle (1 l) filled with $20 \mu \mathrm{m}$ mesh-filtered seawater to remove potential food particles and organ- 
isms. Between 6 and 57 (mean $=23$ ) euphausiids were incubated per oceanographic station for $48 \mathrm{~h}$ in complete darkness to avoid unnecessary stress to the animals and avoid a negative effect of captivity on measured vital rates and survival. Incubations occurred in a cold room at $16 \pm 1^{\circ} \mathrm{C}$ ), the mean temperature at which $N$. simplex are found in their vertical distribution throughout the year (GómezGutiérrez et al. 2010a, Tremblay et al. 2010). We incubated a total of 627 individuals during 6 oceanographic cruises carried out along the Gulf of California (Table 1).

\section{Growth measurements}

The standard instantaneous growth rate method (Tarling et al. 2006) was used to estimate the $\mathrm{Nyc}_{\mathrm{C}}$ tiphanes simplex growth increment (GI, in \%) and DGR $\left(\mathrm{mm} \mathrm{d}^{-1}\right)$. Each incubated specimen was observed every $12 \mathrm{~h}$ during the first $48 \mathrm{~h}$ incubation period, and no food was provided, to detect when euphausiids molt and measure them alive before and after molting.

Total length ( $L$, from the forward rim of the carapace to the tip of the telson) of each Nyctiphanes sim-

Table 1. Nyctiphanes simplex. Abundances observed under shipboard laboratory conditions during $2 \mathrm{~d}$ incubations at $16^{\circ} \mathrm{C}$, grouped by cruise. $N_{\text {inc: }}$ no. of krill incubated (1 per bottle), $N_{\text {dead }}$ : no. of dead krill during incubation, $N$ : total no. of krill that were alive at the end of the experiment plus those krill that molted during the incubation period, m: no. of molted krill, $\% m$ : percentage of molted krill. Intermolt period (IMP) was estimated according to Tarling et al. (2006) (see Eq. 4). Cruise totals are summed abundances, and averaged \%m and IMP

\begin{tabular}{|c|c|c|c|c|c|c|c|c|}
\hline $\begin{array}{l}\text { Initial incubation } \\
\text { date }\end{array}$ & Stn & $\begin{array}{c}\text { Location } \\
\left.\text { (Lat. }{ }^{\circ} \mathrm{N}, \text { Long. }{ }^{\circ} \mathrm{W}\right)\end{array}$ & $N_{\text {inc }}$ & $N_{\text {dead }}$ & $N$ & $m$ & $\% m$ & $\begin{array}{c}\text { IMP } \\
\text { (d) }\end{array}$ \\
\hline 23 Nov 2005 & 24 & $28^{\circ} 04.610^{\prime}, 111^{\circ} 31.922^{\prime}$ & 8 & 1 & 7 & 2 & 28.6 & 7.0 \\
\hline 23 Nov 2005 & 28 & $28^{\circ} 05.115^{\prime}, 112^{\circ} 40.264^{\prime}$ & 57 & 2 & 55 & 27 & 49.1 & 4.1 \\
\hline \multirow[t]{2}{*}{25 Nov 2005} & 34 & $29^{\circ} 47.698^{\prime}, 112^{\circ} 10.514^{\prime}$ & 20 & 0 & 20 & 10 & 50.0 & 4.0 \\
\hline & Total & & 85 & 3 & 82 & 39 & 47.6 & 4.2 \\
\hline 18 Jan 2007 & 34 & $29^{\circ} 30.709^{\prime}, 112^{\circ} 37.722^{\prime}$ & 30 & 11 & 19 & 3 & 15.8 & 12.7 \\
\hline 19 Jan 2007 & 43 & $28^{\circ} 53.077^{\prime}, 113^{\circ} 14.144^{\prime}$ & 29 & 9 & 20 & 5 & 25.0 & 8.0 \\
\hline 20 Jan 2007 & $62-63$ & $27^{\circ} 44.787^{\prime}, 111^{\circ} 58.973^{\prime}$ & 30 & 0 & 30 & 15 & 50.0 & 4.0 \\
\hline 24 Jan 2007 & 89 & $28^{\circ} 27.375^{\prime}, 112^{\circ} 05.846^{\prime}$ & 23 & 1 & 22 & 6 & 27.3 & 7.3 \\
\hline \multirow[t]{2}{*}{25 Jan 2007} & 100 & $20^{\circ} 20.520^{\prime}, 112^{\circ} 47.252^{\prime}$ & 28 & 0 & 28 & 7 & 25.0 & 8.0 \\
\hline & Total & & 140 & 21 & 119 & 36 & 30.3 & 6.6 \\
\hline 21 Jul 2007 & 4 & $30^{\circ} 37.903^{\prime}, 113^{\circ} 57.546^{\prime}$ & 30 & 21 & 9 & 3 & 33.3 & 6.0 \\
\hline $23 \mathrm{Jul} 2007$ & $\mathrm{IK}_{1} 1^{\mathrm{a}}$ & $30^{\circ} 37.266^{\prime}, 113^{\circ} 56.876^{\prime}$ & 12 & 3 & 9 & 1 & 11.1 & 18.0 \\
\hline 24 Jul 2007 & 13 & $28^{\circ} 46.830^{\prime}, 113^{\circ} 04.288^{\prime}$ & 7 & 3 & 4 & 1 & 25.0 & 8.0 \\
\hline $25 \mathrm{Jul} 2007$ & 14 & $28^{\circ} 33.517^{\prime}, 112^{\circ} 34264^{\prime}$ & 22 & 2 & 20 & 1 & 5.0 & 40.0 \\
\hline 26 Jul 2007 & 18 & $28^{\circ} 31.383^{\prime}, 112^{\circ} 50.328^{\prime}$ & 6 & 1 & 5 & 1 & 20.0 & 10.0 \\
\hline 26 Jul 2007 & 19 & $28^{\circ} 36.460^{\prime}, 112^{\circ} 58.681^{\prime}$ & 7 & 1 & 6 & 1 & 16.7 & 12.0 \\
\hline 26 Jul 2007 & $\mathrm{Bp}^{\mathrm{b}}$ & $27^{\circ} 55.612^{\prime}, 112^{\circ} 43.245^{\prime}$ & 30 & 9 & 21 & 11 & 52.4 & 3.8 \\
\hline 29 Jul 2007 & 36 & $27^{\circ} 56.685^{\prime}, 112^{\circ} 41.948^{\prime}$ & 40 & 4 & 36 & 20 & 55.6 & 3.6 \\
\hline \multirow[t]{2}{*}{30 Jul 2007} & 37 & $27^{\circ} 57.334^{\prime}, 112^{\circ} 41.766^{\prime}$ & 21 & 1 & 20 & 2 & 10.0 & 20.0 \\
\hline & Total & & 175 & 45 & 130 & 41 & 31.5 & 6.3 \\
\hline 11 Mar 2010 & 6 & $28^{\circ} 17.007^{\prime}, 112^{\circ} 32.243^{\prime}$ & 30 & 2 & 28 & 10 & 35.7 & 5.6 \\
\hline 12 Mar 2010 & 7 & $29^{\circ} 24.882^{\prime}, 113^{\circ} 10.306^{\prime}$ & 2 & 0 & 2 & 1 & 50.0 & 4.0 \\
\hline 15 Mar 2010 & 15 & $28^{\circ} 40.372^{\prime}, 113^{\circ} 05.018^{\prime}$ & 30 & 0 & 30 & 13 & 43.3 & 4.6 \\
\hline 19 Mar 2010 & 34 & $29^{\circ} 42.811^{\prime}, 112^{\circ} 43.860^{\prime}$ & 11 & 0 & 11 & 5 & 45.5 & 4.4 \\
\hline 21 Mar 2010 & 40 & $28^{\circ} 34.180^{\prime}, 112^{\circ} 13.386^{\prime}$ & 30 & 9 & 21 & 3 & 14.3 & 14.0 \\
\hline 23 Mar 2010 & 57 & $27^{\circ} 44.466^{\prime}, 112^{\circ} 33.404^{\prime}$ & 30 & 0 & 30 & 1 & 3.3 & 60.0 \\
\hline \multirow[t]{2}{*}{25 Mar 2010} & 80 & $26^{\circ} 32.865^{\prime}, 111^{\circ} 23.814^{\prime}$ & 30 & 3 & 27 & 1 & 3.7 & 54.0 \\
\hline & Total & & 163 & 14 & 149 & 34 & 22.8 & 8.8 \\
\hline 19 Sep 2010 & 25 & $28^{\circ} 27.201^{\prime}, 112^{\circ} 47.738^{\prime}$ & 30 & 1 & 29 & 6 & 20.7 & 9.7 \\
\hline 28 Nov 2011 & 20 & $27^{\circ} 52.011^{\prime}, 111^{\circ} 03.073^{\prime}$ & 34 & 1 & 33 & 7 & 21.2 & 9.4 \\
\hline \multicolumn{3}{|c|}{ Nov 2005, Jan and Jul 2007} & 400 & 69 & 331 & 116 & 35.0 & 5.7 \\
\hline \multicolumn{3}{|c|}{ All cruises } & 627 & 85 & 542 & 163 & 30.1 & 6.7 \\
\hline
\end{tabular}


plex that molted during the incubation was measured from live specimens on board the research vessel. Additionally we measured the telson length (from the posterior part of the sixth abdominal segment to the tip of telson; from a left lateral view) of the animal $\left(T_{\mathrm{a}}\right)$ and of the molt $\left(T_{\mathrm{m}}\right)$, to calculate GI (Tarling et al. 2006):

$$
\text { GI }=\frac{T_{\mathrm{a}}-T_{\mathrm{m}}}{T_{\mathrm{m}}} \cdot 100
$$

We also measured the length of the uropods of animals and molts (from the internal part of the base to the longest tip of the uropod). Although the telson and uropod lengths were significantly correlated (data not shown), the uropods are considerable more mobile, making it difficult to measure them precisely on live specimens, and the uropod measurements had higher standard deviations than telson measurements. Thus, we used the telson length measurements to determine changes in size. The uropod measurements were only used in the few cases where the telson of the animal and/or molt was broken. To minimize bias, the same person (J.G.G.) conducted all measurements with a calibrated micrometer adapted to a Carl Zeiss SV11 stereoscope. DGR $\left(\mathrm{mm} \mathrm{d}^{-1}\right)$ was calculated according to Tarling et al. (2006) as:

$$
\mathrm{DGR}=\frac{L_{\mathrm{pre}} \cdot \mathrm{GI}}{\mathrm{IMP} \cdot 100}
$$

where $L_{\text {pre }}$ is the premolt total length of the animal (mm), GI is growth increment, and IMP is the intermolt period. $\mathrm{L}_{\text {pre }}$ was estimated according to Tarling et al. (2006) as:

$$
L_{\text {pre }}=(L \cdot 100) /(100+\mathrm{GI})
$$

The IMP used in Eq. (2) was estimated averaging all Nyctiphanes simplex measurements of specimens that molted twice on board at each cruise, complemented with estimations of IMP calculated using the 1/MR method (Tarling et al. 2006):

$$
\mathrm{IMP}=\frac{N \cdot d}{m}
$$

where $N$ is the total number of krill that were alive at the end of the experiment plus those krill that molted during the incubation period, $m$ is the number of krill that molted, and $d$ is the duration of the incubation expressed in days ( $2 \mathrm{~d}$ in this instance) (Table 1).

\section{Percentage of the molt weight as a function of body weight}

Recently molted Nyctiphanes simplex $(\mathrm{n}=60)$ and their molts were preserved in $70 \%$ ethanol or $5 \%$ formalin buffered with saturated sodium borate. These preservatives may cause water loss, but this effect is not relevant for measurements of dry weight (DW). The animals and molts were washed with distilled water to remove adhered salts, then dried in preweighed aluminum dishes at $60^{\circ} \mathrm{C}$ for $12 \mathrm{~h}$ and individually weighed using an analytical balance (precision of $0.0001 \mathrm{~g}$ ). The proportion of the molt DW in relation to the animal DW was estimated as: $\left(\mathrm{DW}_{\mathrm{m}} / \mathrm{DW}_{\mathrm{a}}\right) \times 100$.

To estimate the individual and population biomass of molts of Nyctiphanes simplex per oceanographic station, we calculated the mean $\mathrm{DW}_{\mathrm{m}}$ per millimeter total length of krill specimens collected with a $505 \mu \mathrm{m}$ mesh Bongo net (equipped with a digital flowmeter; see 'Juvenile and adult biomass per sampling station' below).

\section{Direct observation of IMP and IBP}

A total of 105 Nyctiphanes simplex specimens were incubated for 6 to $15 \mathrm{~d}$ during different cruises that typically lasted $21 \mathrm{~d}$, fed with an in situ mix of plankton sieved through $20 \mu \mathrm{m}$ mesh and kept at a constant temperature $\left(16^{\circ} \mathrm{C}\right)$ in dark conditions to measure IMP and IBP of specimens that molted or spawned twice during each cruise (checked every $12 \mathrm{~h}$ ). To estimate $N$. simplex egg production rates (EPR), we used the IBP observed in 12 out of 55 females collected along the west coast of the Baja California peninsula (Gómez-Gutiérrez \& Robinson 2005) and EPR observed for 11 other females that spawned twice during our 2005 to 2010 shipboard incubations of up to $15 \mathrm{~d}$ in the Gulf of California.

\section{Brood size and brood dry weight}

Each Nyctiphanes simplex female that spawned during the shipboard incubations was removed from the bottle and the number of eggs in the ovigerous sacs was counted to determine brood size (BS, no. of eggs female ${ }^{-1}$ ). We identified the development stage of live embryos following Gómez-Gutiérrez \& Robinson (2005). We also measured the chorion diameter of at least 10 embryos (preferably spherical embryos) to calculate the average embryo diameter $\left(D_{\mathrm{e}}\right)$. The 
average volume of embryos $\left(V_{\mathrm{e}}\right)$ was calculated using the equation for a sphere $\left(4 \pi r^{3} / 3\right)$, where $r$ is the average embryo radius (in $\mu \mathrm{m}$ ). The carbon content of the embryo was estimated using the carbonto- $V_{\mathrm{e}}$ ratio of $1.37 \times 10^{-7} \mu \mathrm{g} \mathrm{C} \mu \mathrm{m}^{-3}$ determined by Gómez-Gutiérrez et al. (2007). This embryo carbon weight was transformed to dry weight $\left(\mathrm{DW}_{\mathrm{e}}\right)$, assuming that the weight of carbon is $40 \%$ of $\mathrm{DW}_{\mathrm{e}}$. To estimate the biomass of the entire ovigerous sac, the mean $\mathrm{DW}_{\mathrm{e}}$ was multiplied by the BS of each $\mathrm{NyC}_{\mathrm{C}}$ tiphanes simplex female.

\section{Juvenile and adult biomass per sampling station}

Juveniles and adults of Nyctiphanes simplex were sorted from zooplankton samples that had been collected with $505 \mu \mathrm{m}$ mesh Bongo net towed obliquely using standard protocols $(<300 \mathrm{~m}$ maximum sampling depth) (Smith \& Richardson 1977). Samples with $>16 \mathrm{ml}$ of zooplankton biovolume were divided using a Folsom splitter into aliquots no larger than 1/16. At each sampling station, the total length of 30 to 100 randomly selected N. simplex juveniles and adults was measured. DW of each measured animal was estimated using an $N$. simplex weight-length regression equation $(\mathrm{DW}=$ $0.005371 \times L^{2.31596}, \mathrm{r}^{2}=0.76$, krill size range $=5$ to $16 \mathrm{~mm}$ ) determined by Gómez-Gutiérrez \& Robinson (1997). N. simplex juvenile and adult abundances were standardized to ind. $1000 \mathrm{~m}^{-3}$. The $N$. simplex biomass $(B)$ per station was calculated using the abundance (ind. $1000 \mathrm{~m}^{-3}$ ) of each $1 \mathrm{~mm}$ total length interval $\left(N_{i}\right)$ of the total sample, assuming those animals had a similar relative size-frequency distribution of the 30 to 100 measured individuals using the following equation:

$$
B=\sum \mathrm{DW}_{i} \cdot N_{i}
$$

\section{Estimation of biomass production rates}

\section{Somatic growth}

The somatic growth production (SGPR, $\mathrm{mg} \mathrm{DW} \mathrm{m}^{-3}$ $\mathrm{d}^{-1}$ ) was estimated using the following equation:

$$
\mathrm{SGPR}=\sum \mathrm{DGR}_{i} \cdot B_{i}
$$

where $\mathrm{DGR}_{i}$ and $B_{i}$ are the daily growth rate and biomass, respectively, in each $1 \mathrm{~mm}$ total length interval $i$ (juveniles and adults) expressed as DW and stan- dardized per $\mathrm{m}^{3}\left(\mathrm{mg} \mathrm{DW} \mathrm{m}^{-3}\right)$. The molt production rate $\left(\mathrm{MPR}, \mathrm{mg} \mathrm{DW} \mathrm{m}^{-3} \mathrm{~d}^{-1}\right)$ was estimated as:

$$
\mathrm{MPR}=\sum \frac{\mathrm{DW}_{\mathrm{a}} \cdot \% \mathrm{DW} \cdot N_{i}}{\mathrm{IMP}}
$$

where $\mathrm{DW}_{\mathrm{a}}$ is the Nyctiphanes simplex size-specific dry weight (in $\mathrm{mg}$ ) of the animal estimated from total length, $\% \mathrm{DW}_{\mathrm{m}}$ is the size-specific percentage of the molt dry weight in relation to the body dry weight, IMP $_{\text {med }}$ is the median IMP (in d) per oceanographic cruise, and $N_{i}$ is the abundance of krill in each $1 \mathrm{~mm}$ total length interval (ind. $\mathrm{m}^{-3}$ ).

Egg production rate $\left(E P R, \mathrm{mg} \mathrm{DW} \mathrm{m}^{-3} \mathrm{~d}^{-1}\right.$ ) was calculated according to Winberg (1971) and Lavaniegos (1995):

$$
\mathrm{EPR}=\frac{\mathrm{DW}_{\mathrm{e}}}{\mathrm{IBP}_{\text {mean }}} \sum \frac{\left(\mathrm{BS}_{i}+\mathrm{BS}_{i+1}\right) \cdot N_{i}}{2}
$$

where $\mathrm{DW}_{\mathrm{e}}$ is the total embryo dry weight contained at each ovigerous sac (mg DW brood ${ }^{-1}$ female $^{-1}$ ), $\mathrm{IBP}_{\text {mean }}$ is the mean interbrood period per oceanographic cruise (d), $\mathrm{BS}_{\mathrm{i}}$ is the brood size per size interval (eggs female ${ }^{-1}$ ), and $N_{i}$ is the standardized abundance of females per size interval at each oceanographic station (ind. $\mathrm{m}^{-3}$ ). We used the median IBP of $10 \mathrm{~d}$ (range: 7 to $15 \mathrm{~d}$ ) reported from the same cruises (Gómez-Gutiérrez et al. 2010b). Mean hatching time was fixed to $5 \mathrm{~d}$ and mean just spawned embryo diameter was $384 \mu \mathrm{m}$ (range: 345 to $465 \mu \mathrm{m}$ ) (Gómez-Gutiérrez \& Robinson 2005), with an estimated mean embryo dry weight of $10.2 \mu \mathrm{g}$ (range: 7.4 to $18.0 \mu \mathrm{g}$ ). Egg production rates were estimated using ovigerous female-specific mean egg embryo diameter to estimate their dry weight of eggs of each female.

\section{Annual population biomass}

We estimated the integrated production rate (IPR, mg DW m ${ }^{-3} \mathrm{yr}^{-1}$ ) here defined as the Nyctiphanes simplex total production rate (TPR; somatic, molt and egg production) as a function of time $(t)$ integrated over an annual interval (estimated for the cold, warm, and transitional seasons) according to Kimmerer (1987):

$$
\mathrm{IPR}=\int_{t 1}^{t 2} \mathrm{TPR} \cdot \mathrm{d} t
$$

Using the estimated Nyctiphanes simplex integrated biomass and biomass production rates from each oceanographic station, we extrapolated these estimations to the total distribution range of this species within the area of study. We used the average $N$. 
simplex abundance recorded at each $50 \mathrm{~m}$ seafloor depth interval $(0-50,51-100,101-150$, and 150$200 \mathrm{~m}$ ) to estimate total instantaneous population biomass. The area of the $N$. simplex distribution in each $50 \mathrm{~m}$ depth interval along the continental shelf (calculated from a digital bathymetry data set) was estimated using the software ImageJ (http://rsbweb.nih.gov/ij/) and the number of pixels of each seafloor depth interval were compared with the calibration area of $1^{\circ} \times 1^{\circ}$ (latitude and longitude) equivalent to $12361 \mathrm{~km}^{2}$. The seawater volume for each seafloor depth interval was estimated assuming an average depth. In regions with $>200 \mathrm{~m}$ depth (oceanic region), the volume was estimated only considering the volume of the first $200 \mathrm{~m}$ of the water column depth, which is the core of the vertical distribution range of N. simplex in the Gulf of California (Lavaniegos 1996, Tremblay et al. 2010) and is where bongo net was deployed (maximum sampling depth of $280 \mathrm{~m}$ ). We extrapolated the estimated N. simplex biomass and biomass production rates to these volumes for each $50 \mathrm{~m}$ seafloor depth interval.

\section{Multivariate association of biomass and biomass production rates with environmental conditions}

Nyctiphanes simplex biomass and biomass production rates (body growth, molt, and egg production) were associated with multiple environmental variables recorded at each oceanographic station using Bray-Curtis cluster analysis. Based on the main BrayCurtis cluster analysis groups, we performed a nonmetric multidimensional scaling (NMDS) which allowed us to determine how the distribution and magnitude of the $N$. simplex biomass and biomass production rates varied as a function of the 12 environmental variables: SST $\left({ }^{\circ} \mathrm{C}\right)$, depth of the mixed layer $(\mathrm{m})$, depth of the oxygen minimum zone (m), depth of maximum chl a concentration (m), seafloor depth at the oceanographic station (m), watercolumn integrated $\mathrm{chl}$ a concentration $\left(\mathrm{mg} \mathrm{m}^{-2}\right)$, integrated concentration of accessory pigments peridinin, alloxanthin, zeaxanthin, chl $b$, fucoxanthin $\left(\mathrm{mg} \mathrm{m}^{-2}\right)$, zooplankton biomass $\left(\mathrm{ml} \mathrm{m}^{-3}\right)$, and the categorical variables sampling month (November, January, or July), region (following criteria of Lavin \& Marinone 2003-northern Gulf, Midriff Archipelago region, and central Gulf), and environment (neritic: $<200 \mathrm{~m}$ seafloor depth; oceanic: > $200 \mathrm{~m}$ seafloor depth). This exploratory multivariate analysis was conducted using the software PC-ORD v. 6.0 (McCune \& Mefford 1999, McCune et al. 2002).
The NMDS allow us to identify the main modes of variability of Nyctiphanes simplex biomass and biomass production rates (components). Using a multiresponse permutational procedure (MRPP), we tested several null hypotheses $\left(\mathrm{H}_{0}\right)$ to detect if there were significant differences in biomass and biomass production among different groups: (1) oceanographic stations previously defined in the Bray-Curtis cluster analysis, (2) by season, (3) by region, and (4) under specific environmental conditions (McCune \& Mefford 1999, McCune et al. 2002). Both NMDS and MRPP are non-parametric tests that do not require the biological data (biomass and total biomass production) to be normally distributed.

\section{RESULTS}

\section{Environmental variability}

The description of the environmental conditions (vertical profiles and maps) of temperature, salinity, chl $a$, and dissolved oxygen concentrations recorded during these 3 oceanographic cruises were reported by Gómez-Gutiérrez et al. (2010a) and Tremblay et al. (2010).

Satellite sea surface temperature per oceanographic cruise. During November 2005, considered as a seasonal transition period, satellite SST ranged from 21 to $26^{\circ} \mathrm{C}$ with a clear latitudinal gradient (Fig. 2A). In January 2007, the SST was lower (16 to $20^{\circ} \mathrm{C}$ ) than in November but also showed a latitudinal gradient (Fig. 2B). In July, SST substantially increased (reaching 27 to $30^{\circ} \mathrm{C}$ ), displaying a typical longitudinal temperature gradient with higher SST along the east coast of the Gulf (Fig. 2C). Overall, the Midriff Archipelago region (known in Spanish as 'Grandes Islas') was the coldest area during the 3 cruises (Fig. 2A-C).

Satellite surface chl a concentration per oceanographic cruise. During November 2005, the chl a concentration was very high along the east coast of the Gulf of California, particularly around Tiburón Island, Guaymas, and the southernmost region of the area of study, associated with coastal upwelling processes and high depths of the mixed layer that occur near Tiburón Island (Fig. 2D). During January 2007, the chl a concentration was high in the Midriff Archipelago region and along the east coast of the Gulf, likely associated with wind induced coastal upwelling (Fig. 2E). During July 2007, surface chl a concentration decreased in most of the Gulf, but relatively higher concentrations were detected around 


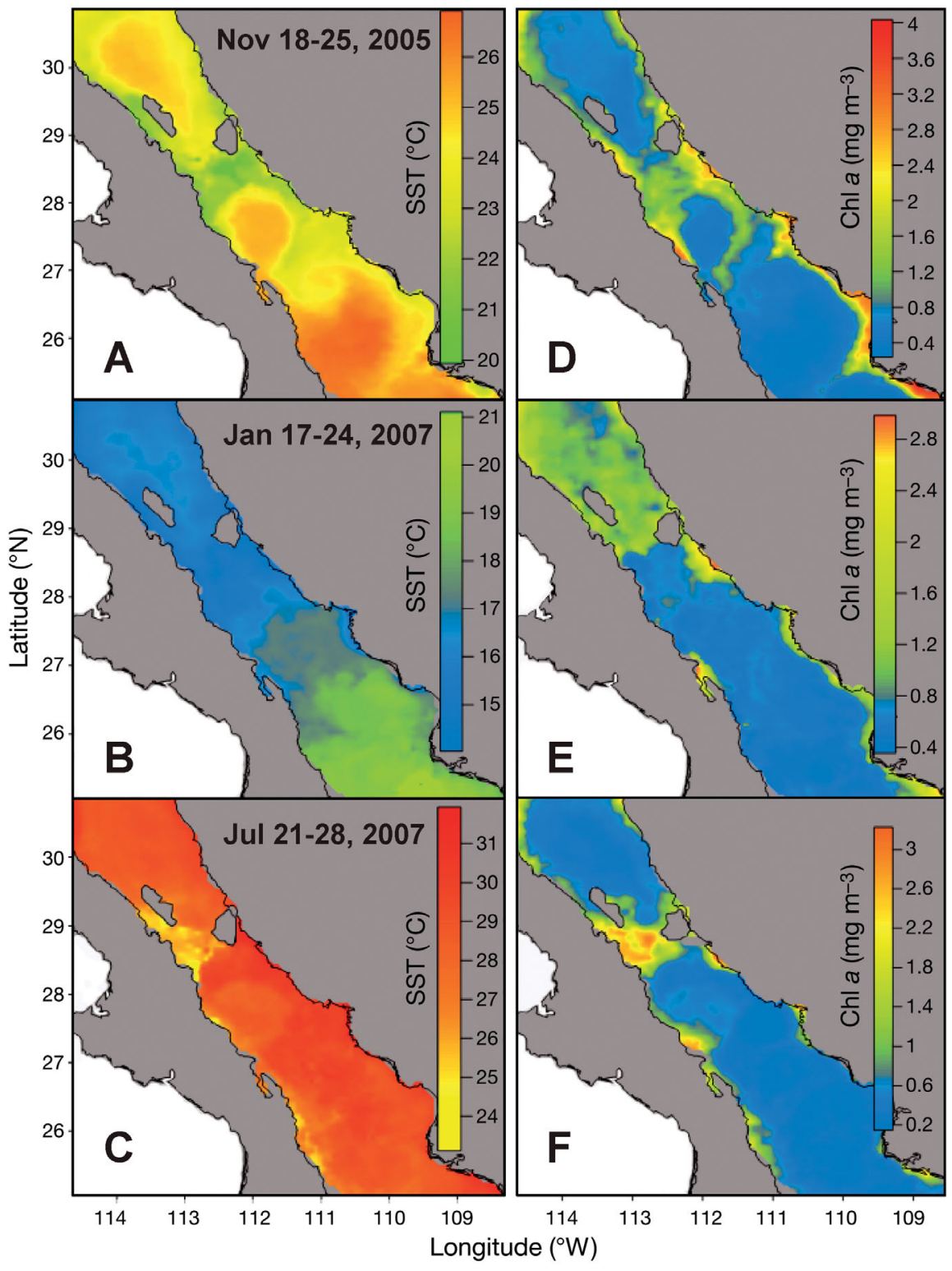

Fig. 2. (A-C) Monthly mean sea surface temperature (SST) and (D-F) chl a concentration obtained from satellite imagery during (A,D) November 2005, (B,E) January and (C,F) July 2007

the Midriff Archipelago region and along the mainland coast of the Gulf of California (Fig. 2F).

\section{Biological variability}

Total length frequency distribution. Juveniles ( $<8 \mathrm{~mm}$ total length) were commonly found during the November (43\% of the total catch) and July (56\%) cruises. Larger adults $(<22 \mathrm{~mm}$, both sexes) were detected during November and January than during July (females $<12 \mathrm{~mm}$ and males $<14 \mathrm{~mm}$ ) (Fig. 3A-C).
Biomass. In November, Nyctiphanes simplex juveniles and adults biomass was $>1000 \mathrm{mg}$ DW $1000 \mathrm{~m}^{-3}$ along the northeast coast of the Gulf, particularly north and south of Tiburón Island. Biomass ranged from 100 to $999 \mathrm{mg}$ DW $1000 \mathrm{~m}^{-3}$ around the Angel de La Guarda Island and south of Guaymas. The rest of the Gulf had low N. simplex biomass $\left(<99 \mathrm{mg}\right.$ DW $\left.1000 \mathrm{~m}^{-3}\right)$ (Fig. 4A-C). In January, the highest biomass range $(>1000 \mathrm{mg}$ DW $1000 \mathrm{~m}^{-3}$ ) of $N$. simplex juveniles and adults occurred along the northwest part of the Gulf, Midriff Archipelago region, and Guaymas Bay. Biomasses from 100 to $999 \mathrm{mg}$ DW $1000 \mathrm{~m}^{-3}$ were detected along the western coast off San Carlos Bay and Concepción Bay (Fig. 4D-F). During July, N. simplex biomass >1000 mg DW $1000 \mathrm{~m}^{-3}$ occurred in the central region of the northern Gulf, San Carlos Bay, and Guaymas Bay. Biomasses ranging from 100 to $999 \mathrm{mg}$ DW $1000 \mathrm{~m}^{-3}$ were distributed along the west coast of the Gulf. Low or no biomass of $N$. simplex was detected along the east coast of the Gulf (Fig. 4G-I). Overall, adults contributed most of the total euphausiid biomass. Peak biomasses regions of $N$. simplex populations shifted from east (November), to northwest (January), to west (July), indicating that $N$. simplex has a seasonal increase of biomass in regions with relatively low temperatures (Fig. 4A-I).

\section{Shipboard experimentally estimated vital rates}

Intermolt period. Juveniles and adults (both sexes combined) had a mean IMP (observed between 2 successive molts of the same individual) of $5 \mathrm{~d}$ during January (range: 3 to 7 d) and 3.8 d during July (range: 2 to 8 d) (Fig. 5A). From September to October 2010, we observed a mean IMP of $4.4 \mathrm{~d}$ (range: 3 to $7 \mathrm{~d}, \mathrm{n}=22$ ). Based on these data, SeptemberOctober 2010 also appears to be part of the transitional period and we therefore used $4.4 \mathrm{~d}$ as proxy for the November IMP. The only significant mean differences of the IMP were detected between Jan- 


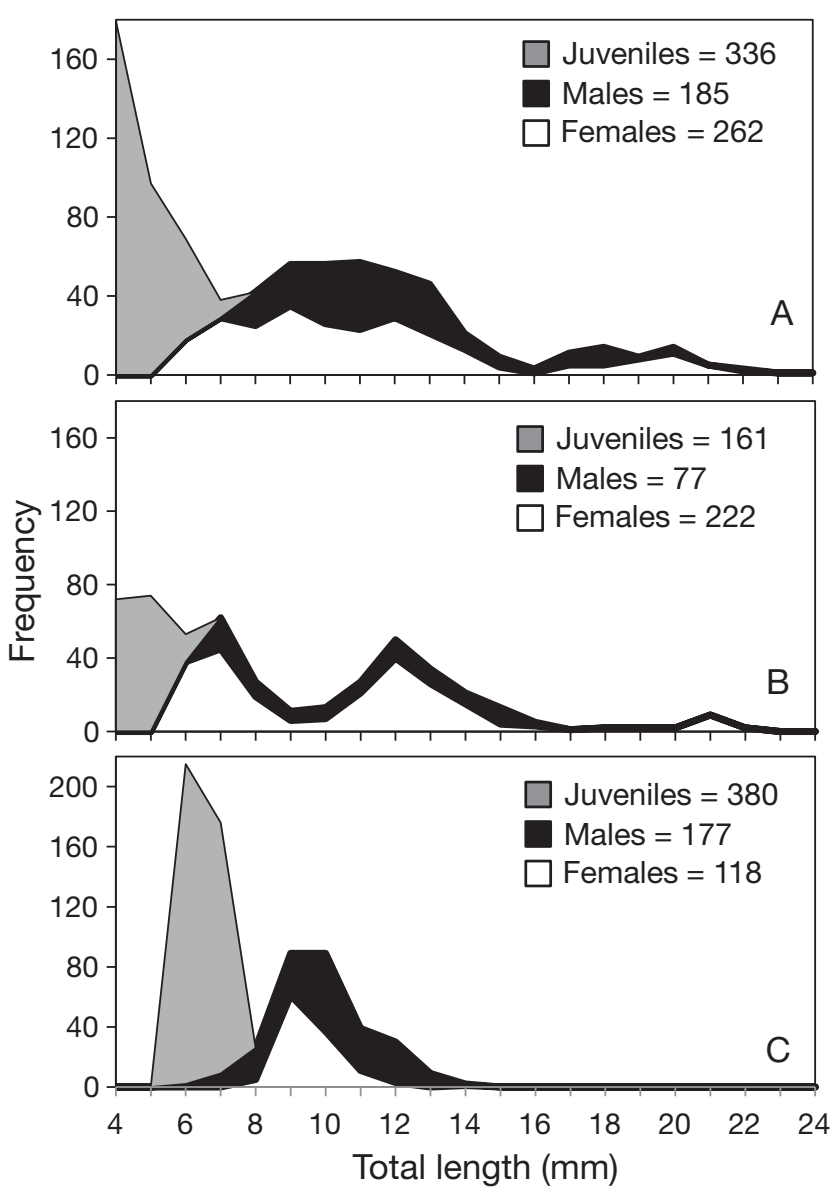

Fig. 3. Nyctiphanes simplex. Total length frequency distribution of juveniles, and adult males and females (no. of specimens given in key) measured during oceanographic cruises in (A) November 2005, (B) January 2007 and (C) July 2007

uary and July ( $t$-test: $t=2.2083, \mathrm{p}=0.05)$. We used the observed mean IMP per cruise to estimate the somatic growth and molt production rates for juveniles and male adults because a regression of DGR as a function of $L_{\text {pre }}$ typically accounted for $<10 \%$ of variability, but the slope was not significant $(\mathrm{p}>$ 0.05) (Fig. 5B). Considering that most of the females spawn with IBP $\geq 7 \mathrm{~d}$ (the longest IBP estimated for this species was $26 \mathrm{~d}$ ), the ovigerous females' IMP must be $>7 \mathrm{~d}$. This IMP is evident because an ovigerous female typically does not molt before releasing the embryos from its ovigerous sac. Thus, we assumed that the Nyctiphanes simplex females $>8 \mathrm{~mm}$ long had an average IBP of $10 \mathrm{~d}$ (range: 7 to 26 d) (Gómez-Gutiérrez et al. 2010b) and a mean IMP of $9 \mathrm{~d}$.

Daily growth rate. The mean $L_{\text {pre }}$ GI, and DGR per oceanographic station per cruise are summarized in Table 2. Only positive DGR per stations were included in the estimation of body growth rates. The instantaneous growth rate method (Tarling et al. 2006) assumes that the quality and concentration of food consumed before collection was metabolized and eventually converted into euphausiid biomass (somatic growth, molt, and/or eggs) (Kawaguchi et al. 2006, Tarling et al. 2006, GómezGutiérrez et al. 2007). To test this assumption, we frequently incubated Nyctiphanes simplex for longer periods (up to $216 \mathrm{~h}$ ) to detect the mean time when most krill stopped growing or decreased in size due to fasting and/or captivity effects (Fig. 6A,B). $N$. simplex DGR as a function of incubation time per oceanographic cruise showed that on average specimens did not grow $(\mathrm{DGR}=0)$ and tended to decrease in size (negative DGR) starting at 65 to 83 $\mathrm{h}$ (mean $77 \mathrm{~h}$ ) in captivity. Incubation time typically accounted for $<22 \%$ of the variation of DGR, but this was not statistically significant $(p>0.05)$. The predicted mean DGR reached zero at $78 \mathrm{~h}$ (November), $81 \mathrm{~h}$ (January), and $63 \mathrm{~h}$ (March) of incubation (Fig. 6A). Because most positive DGR values were detected within $<48 \mathrm{~h}$, we concluded that incubations $<48$ h likely reflect $N$. simplex growth rates from field conditions. Therefore, only $<48 \mathrm{~h}$ growth rates were used for statistical analyses (Fig. 6A,B). Mean DGR was linearly correlated to $L$ for each oceanographic cruise (Fig. 5B). On average, the DGR was larger in juveniles than in adults. Mean $( \pm \mathrm{SE})$ positive DGR was significantly higher in January $\left(0.107 \pm 0.015 \mathrm{~mm} \mathrm{~d}^{-1}\right)$ than in November $(0$. $\left.072 \pm 0.013 \mathrm{~mm} \mathrm{~d}^{-1}\right)$ and July $\left(0.030 \pm 0.005 \mathrm{~mm} \mathrm{~d}^{-1}\right)$ (Kruskal-Wallis, $\mathrm{p}<0.05$ ). The regression equation for total length and DGR for each sampling month was used to estimate SGPR for each oceanographic cruise (Fig. 5B). DGR indicated that $N$. simplex did not grow $(\mathrm{DGR}=0$ ) or decreased in size $(\mathrm{DGR}<0)$ during all seasons, with higher proportions in July (21 and $52 \%$, respectively) than in January ( 7 and $43 \%$ ) and November (35 and 12\%). The proportion of individuals that grew was nearly 2-fold greater in November (54\%) and January (50\%) than in July $(27 \%)$. Thus, the most favorable environmental conditions for $N$. simplex body growth prevailed during November and January (Fig. 5C, 6A,B).

Brood size. The Nyctiphanes simplex BS was directly proportional to the female total length $(L$, in $\mathrm{mm} ; \mathrm{BS}=-52.30+8.33 \times L, \mathrm{r}^{2}=0.4114, \mathrm{p}<0.05, \mathrm{n}=45$ females) (Fig. 5D). Average BS of females $<10 \mathrm{~mm}$ long was $<40$ eggs female ${ }^{-1}$. The maximum average BS produced by females at individual stations was 85 eggs female ${ }^{-1}$, but the overall $N$. simplex BS range was 5 to 116 eggs female ${ }^{-1}$. 


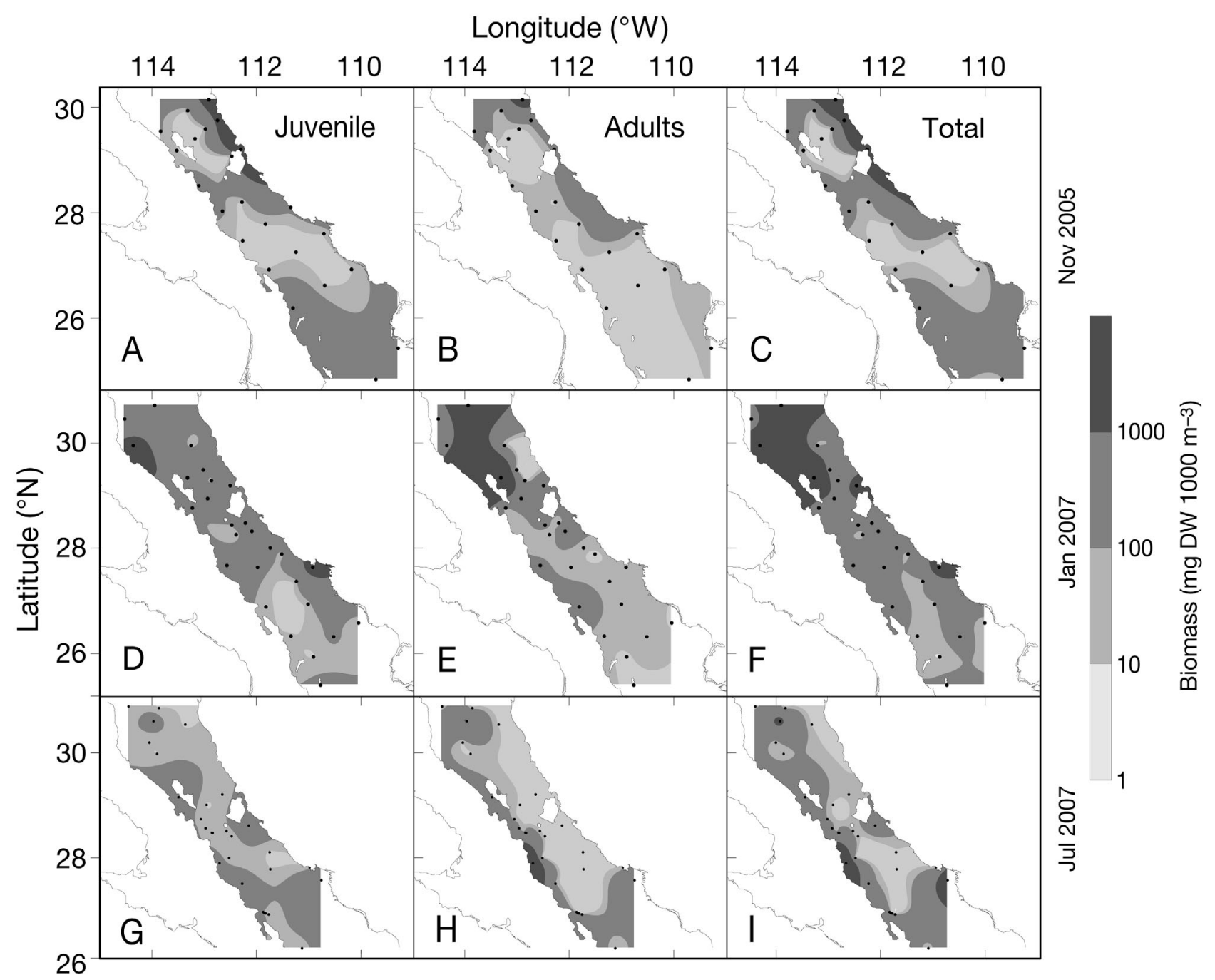

Fig. 4. Nyctiphanes simplex. Distribution of biomass (mg DW $1000 \mathrm{~m}^{-3}$ ) of $(\mathrm{A}, \mathrm{D}, \mathrm{G})$ juvenile, $(\mathrm{B}, \mathrm{E}, \mathrm{H})$ adults and $(\mathrm{C}, \mathrm{F}, \mathrm{I})$ total biomass (juvenile and adults) estimated during (A-C) November 2005, (D-F) January 2007 and (G-I) July 2007

\section{Biomass production rates}

Nyctiphanes simplex juvenile and adult total biomass production (somatic, molt, and egg production) estimated during November 2005 was $>0.1 \mathrm{mg}$ DW $\mathrm{m}^{-3} \mathrm{~d}^{-1}$, mostly concentrated north and south of Tiburón Island (Fig. 7A-C). Total biomass production values between 0.01 and $0.09 \mathrm{mg} \mathrm{DW} \mathrm{m} \mathrm{m}^{-3} \mathrm{~d}^{-1}$ were found along the northern and northeastern portion of the Midriff Archipelago region up to Guaymas Bay (Fig. 7D). Biomass production rates $<0.01 \mathrm{mg} \mathrm{DW} \mathrm{m}^{-3}$ $\mathrm{d}^{-1}$ were detected in the rest of the Gulf (Fig. 7A-D). During January 2007, the total biomass production was considerably higher along the northern part of the Gulf and around Isla Angel de la Guarda region $\left(>0.1 \mathrm{mg} \mathrm{DW} \mathrm{m}{ }^{-3} \mathrm{~d}^{-1}\right.$ ) than in November 2005
(Fig. 7H). The northeastern portion of the Gulf, San Carlos Bay, and Concepción Bay regions showed total production rates between 0.01 and $0.09 \mathrm{mg}$ DW $\mathrm{m}^{-3} \mathrm{~d}^{-1}$. In the rest of the area of study, we estimated low biomass production rates of $<0.01 \mathrm{mg} \mathrm{DW} \mathrm{m}^{-3} \mathrm{~d}^{-1}$ (Fig. 7E-H). During July 2007, the total biomass production decreased significantly with values from 0.01 to $0.09 \mathrm{mg} \mathrm{DW} \mathrm{m} \mathrm{m}^{-3} \mathrm{~d}^{-1}$ in the northern Gulf, San Carlos Bay, and Guaymas Bay (Fig. 7L). During November and January, the N. simplex total biomass production showed a latitudinal gradient with a decreasing trend from north to south. During July, $N$. simplex showed a decreasing biomass production gradient from the west coast to the east coast, with the exception of the Yavaros area, which had relatively high biomass production rates (Fig. 7I-L). 


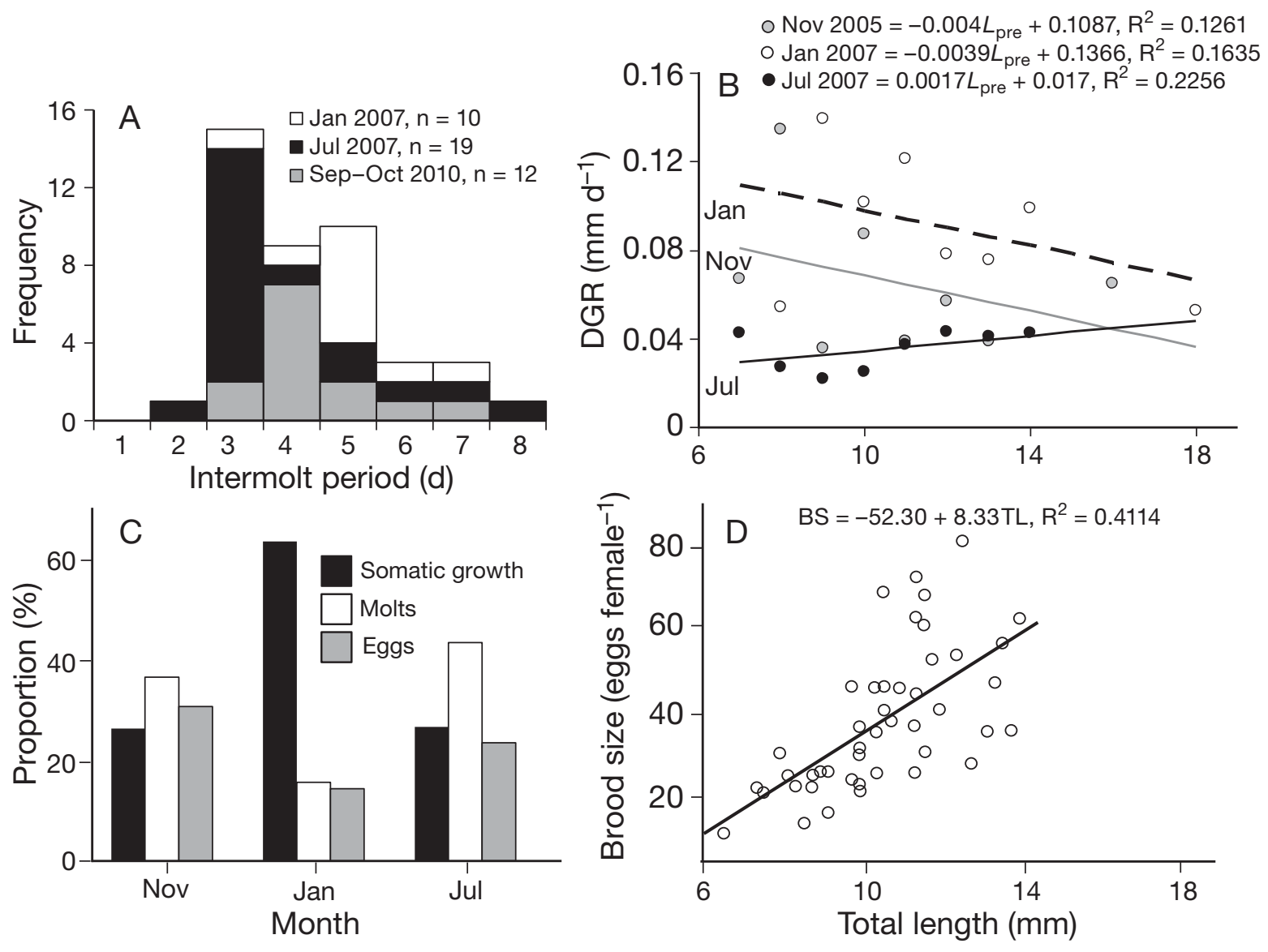

Fig. 5. Nyctiphanes simplex. (A) Observed intermolt period frequency distribution recorded during January and July 2007, and September to October 2010, (B) Predicted regression slopes of the size-specific daily growth rate per oceanographic cruise, (C) percentage of somatic growth, molt production, and egg production in relation to total biomass production in November 2005, January 2007 and July 2007, and (D) linear regression model of the brood size as a function of individual female total length $(\mathrm{n}=45)$

Biomass and biomass production rates as a function of environmental conditions. The Bray-Curtis cluster analysis of Nyctiphanes simplex biomass production rates (Fig. 8A) showed 4 groups ( $45 \%$ similarity cutoff), each one including invariably oceanographic stations from each cruise (meaning no clear pattern of seasonal change). The cluster analysis formed groups including regions with similar magnitude (high, intermediate, low and lowest range) of biomass production rates (all cruises combined) that vary geographically in the Gulf throughout the year moving from the east coast of the Gulf in November, to the northwestern Gulf in January, to the east coast of the Gulf in July (Figs. 7A-L, 8A,B). The first axis $\left(r^{2}=0.718\right)$ and second axis $\left(r^{2}=0.026\right)$ of the NMDS analysis represent about $74 \%$ of the total variability (Table 3, Fig. 8B). The vectors indicating the main mode of variability of biomass and biomass production rates along the first axis were directly associated with the depth of the mixed water layer, seafloor depth (neritic vs. oceanic habitats), and the concentration of the accessory pigment alloxanthin, indicator of the presence of cryptophytic phytoplankton. The first axis was also directly, but less strongly, associated with the depth of the maximum chl a concentration (which indicates a relative increase of food availability in regions with deeper mixing layers) (Table 3). The second axis was directly associated with the zooplankton biomass and the concentration of the accessory pigment alloxanthin, and inversely (and only slightly) associated with the seafloor depth, and the depths of the maximum chl $a$ and chl $b$ concentrations (Table 3 ).

Nyctiphanes simplex intra-specific variability of biomass and biomass production rates (somatic growth, molting, and egg production) was highly aggregated with respect to the multi-dimensional ordination of environmental conditions. As expected, the greatest contribution to $N$. simplex total biomass production rates was from somatic growth of 
Table 2. Nyctiphanes simplex. Mean, minimum, maximum and abundance (N) or standard error (SE) of premolt total length $\left(L_{\text {pre }}\right)$, growth increment (GI) and daily growth rates (DGR) per oceanographic station and per cruise. Station names: see Table 1

\begin{tabular}{|c|c|c|c|c|c|c|c|c|c|c|c|c|c|c|}
\hline \multirow[t]{2}{*}{ Cruise } & \multirow[t]{2}{*}{ Stn } & \multirow[t]{2}{*}{$\mathrm{N}$} & \multicolumn{4}{|c|}{$-L_{\mathrm{pre}}$} & \multicolumn{4}{|c|}{- GI $(\%)$} & \multicolumn{4}{|c|}{$-\mathrm{DGR}\left(\mathrm{mm} \mathrm{d}^{-1}\right)$} \\
\hline & & & Mean & Min & Max & SE & Mean & Min & Max & $\mathrm{SE}$ & Mean & Min & Max & SE \\
\hline \multirow[t]{4}{*}{ Nov 2005} & 24 & 1 & 10.4 & & & & 0.575 & 0.000 & 1.149 & 0.575 & 0.0085 & 0.0000 & 0.0171 & 0.0085 \\
\hline & 28 & 19 & 11.8 & 9.6 & 15.7 & 0.354 & -0.107 & -9.783 & 6.667 & 0.848 & -0.0127 & -0.3754 & 0.1553 & 0.0268 \\
\hline & 34 & 9 & 10.7 & 7.1 & 16.1 & 0.932 & 1.301 & -4.688 & 6.349 & 0.994 & 0.0300 & -0.1109 & 0.1346 & 0.0222 \\
\hline & Mean & & 11.0 & & & & 0.590 & & & & 0.0086 & & & \\
\hline \multirow[t]{6}{*}{ Jan 2007} & 100 & 22 & 14.8 & 9.0 & 17.6 & 0.390 & -1.963 & -15.733 & 7.692 & 1.528 & -0.0483 & -0.3469 & 0.1372 & 0.0298 \\
\hline & $62-63$ & 20 & 10.6 & 7.7 & 17.9 & 0.522 & 2.295 & -5.102 & 13.846 & 1.107 & 0.0564 & -0.1773 & 0.3250 & 0.0283 \\
\hline & 77 & 9 & 10.8 & 7.9 & 13.7 & 0.592 & 5.795 & -1.493 & 16.000 & 1.922 & 0.0679 & -0.0191 & 0.2188 & 0.0244 \\
\hline & 89 & 10 & 12.2 & 11.1 & 13.6 & 0.255 & 1.055 & -6.742 & 7.447 & 1.498 & 0.0147 & -0.1257 & 0.1157 & 0.0250 \\
\hline & 18 & 1 & 19.4 & & & & -2.105 & -2.105 & -2.105 & & -0.0620 & -0.0620 & -0.0620 & \\
\hline & Mean & & 13.6 & & & & 1.015 & & & & 0.006 & & & \\
\hline \multirow{10}{*}{ Jul 2007} & 11 & 6 & 9.6 & 8.0 & 11.9 & 0.520 & 2.629 & -6.593 & 15.190 & 3.899 & 0.0153 & -0.0347 & 0.1003 & 0.0220 \\
\hline & 13 & 5 & 10.5 & 8.9 & 12.0 & 0.577 & -2.229 & -2.597 & -1.316 & 0.233 & -0.0292 & -0.0375 & -0.0181 & 0.0035 \\
\hline & 14 & 11 & 8.2 & 4.5 & 10.4 & 0.547 & 0.299 & -2.941 & 5.357 & 0.685 & 0.0007 & -0.0067 & 0.0121 & 0.0015 \\
\hline & 18 & 2 & 12.1 & 11.4 & 12.8 & 0.702 & -3.690 & -5.000 & -2.381 & 1.310 & -0.0438 & -0.0571 & -0.0305 & 0.0133 \\
\hline & 36 & 33 & 12.7 & 10.4 & 14.2 & 0.166 & -0.655 & -10.000 & 17.647 & 1.166 & -0.0309 & -0.3660 & 0.5358 & 0.0387 \\
\hline & 37 & 11 & 11.5 & 8.7 & 13.6 & 0.385 & -0.692 & -6.410 & 3.846 & 1.048 & -0.0052 & -0.0435 & 0.0232 & 0.0062 \\
\hline & 4 & 8 & 10.2 & 9.1 & 11.2 & 0.284 & -2.623 & -7.778 & 2.740 & 1.322 & -0.0468 & -0.1455 & 0.0413 & 0.0230 \\
\hline & Bp & 25 & 10.6 & 6.7 & 13.7 & 0.489 & -0.966 & -11.111 & 5.000 & 0.751 & -0.0359 & -0.3955 & 0.1570 & 0.0238 \\
\hline & IK11 & 7 & 10.2 & 8.2 & 12.2 & 0.512 & 0.339 & -3.191 & 1.299 & 0.883 & 0.0033 & -0.0551 & 0.0188 & 0.0146 \\
\hline & Mean & & 10.6 & & & & -0.843 & & & & -0.019 & & & \\
\hline \multirow[t]{7}{*}{ Mar 2010} & 15 & 17 & 13.2 & 11.0 & 14.7 & 0.281 & 1.744 & -3.158 & 6.667 & 0.686 & 0.0482 & -0.0995 & 0.1861 & 0.0198 \\
\hline & 34 & 18 & 10.8 & 6.8 & 14.2 & 0.580 & -0.232 & -5.435 & 12.281 & 1.079 & -0.0105 & -0.1624 & 0.1993 & 0.0224 \\
\hline & 40 & 6 & 10.8 & 9.5 & 12.2 & 0.351 & -1.013 & -2.532 & 0.000 & 0.620 & -0.0078 & -0.0195 & 0.0000 & 0.0048 \\
\hline & 57 & 7 & 9.0 & 8.0 & 11.1 & 0.403 & 0.510 & -2.778 & 2.667 & 0.708 & 0.0008 & -0.0045 & 0.0049 & 0.0011 \\
\hline & 6 & 11 & 11.4 & 9.2 & 13.7 & 0.412 & 0.466 & -6.250 & 4.598 & 0.927 & 0.0124 & -0.1093 & 0.1062 & 0.0183 \\
\hline & 7 & 1 & 13.4 & 13.4 & 13.4 & & 5.063 & 5.063 & 5.063 & & 0.1690 & 0.1690 & 0.1690 & \\
\hline & Mean & & 11.4 & & & & 1.090 & & & & 0.035 & & & \\
\hline Sep 2010 & 25 & 44 & 12.8 & 8.6 & 15.5 & 0.244 & -1.095 & -16.667 & 6.667 & 0.666 & -0.017 & -0.258 & 0.067 & 0.0096 \\
\hline Nov 2011 & 20 & 11 & 11.1 & 9.7 & 12.6 & 0.374 & 0.288 & -10.345 & 11.765 & 1.967 & -0.012 & -0.135 & 0.123 & 0.0227 \\
\hline
\end{tabular}

juveniles and adults. The total biomass and total abundance of juveniles were closely clustered with molt production rates, while egg production rates were closely associated with abundance and biomass of N. simplex adults (Fig. 8B).

The NMDS analysis indicated significant differences in the temporal distribution of abundance, biomass, and biomass production rates among latitudinal regions (Table 4). There were significantly higher biomass and production rates at the oceanographic stations distributed throughout the neritic habitat than in the oceanic habitat. This trend confirms Nyctiphanes simplex's neritic zoogeographic affinity, corresponding with areas of higher chl a concentrations (Table 4). The MRPP defined the northern Gulf of California as the region with the greatest krill abundance, biomass, and biomass production rates in comparison with the Midriff Archipelago region and central Gulf. The MRPP confirmed that the largest $N$. simplex biomass production rates were distributed in the northern Gulf during November and January, and in San Carlos Bay during July (Fig. 7).
Daily and annual biomass production. The mean ( \pm SD) daily Nyctiphanes simplex total biomass production rate in the northern and central Gulf of California was $0.163 \pm 0.13 \mathrm{mg} \mathrm{DW} \mathrm{m} \mathrm{m}^{-3} \mathrm{~d}^{-1}$. We estimated a mean annual integrated $N$. simplex total biomass production rate of $71 \pm 58 \mathrm{mg} \mathrm{DW} \mathrm{m}{ }^{-3} \mathrm{yr}^{-1}$ (Table 5) assuming that January estimates represent the production rates of the cold period (December to May, $182 \mathrm{~d}$ ), July for the warm period (July to October, $123 \mathrm{~d}$ ), and November for the 2 transitional periods (June and November, $60 \mathrm{~d}$ ). Highest biomass and biomass production rates occurred during January and the lowest during July (Table 5). N. simplex habitat in the area of study was estimated as $158560 \mathrm{~km}^{2}$. About $69 \%$ of the N. simplex biomass and $57 \%$ of its biomass production occur in regions with $<100 \mathrm{~m}$ depth (Table 5). These regions represent only $27 \%$ of the area of study, indicating that $N$. simplex were concentrated in relatively shallow waters. Extrapolating the mean $N$. simplex biomass and total production rates detected at the 69 oceanographic stations to the habitat area defined by $50 \mathrm{~m}$ seafloor depth 


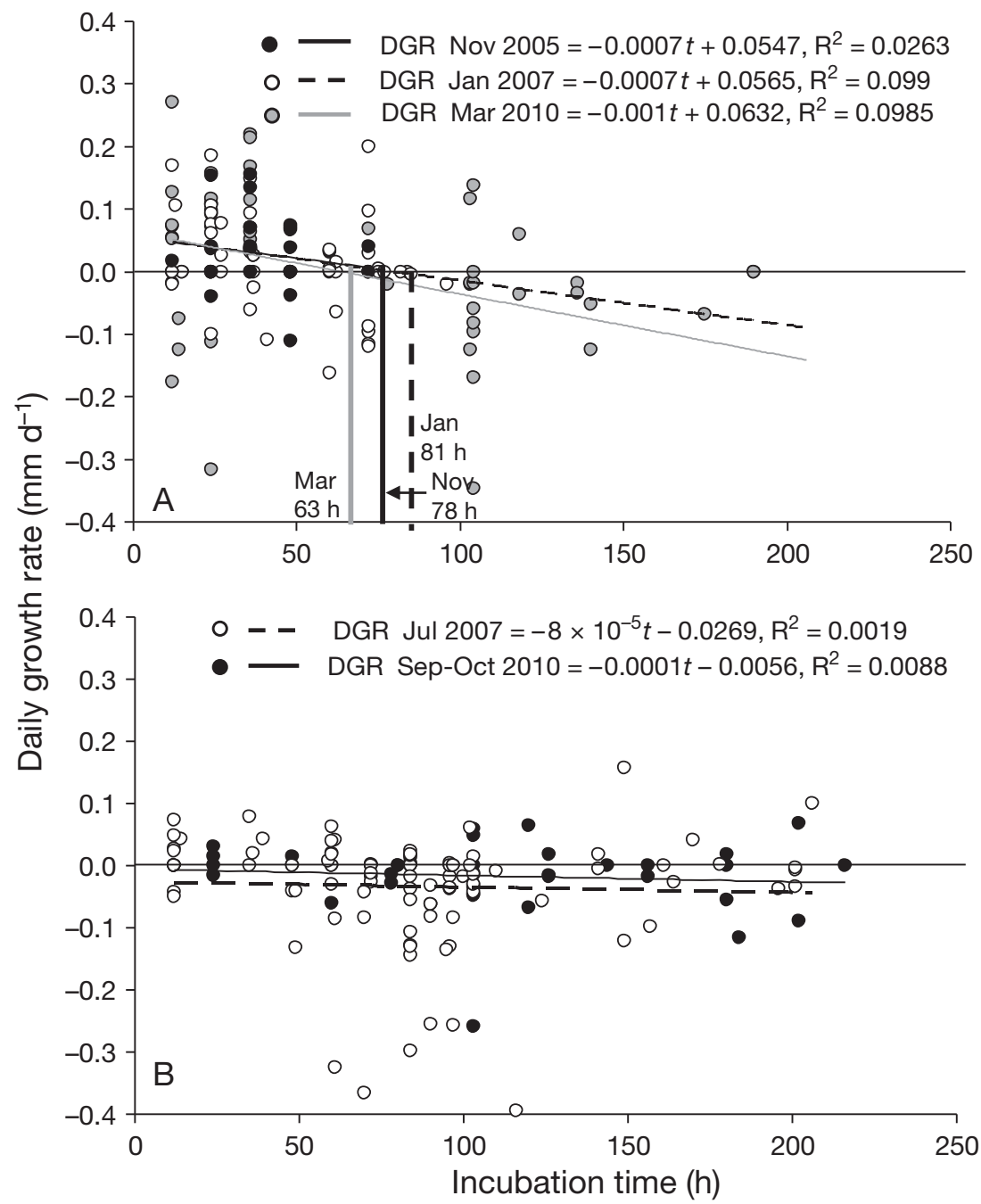

Fig. 6. Nyctiphanes simplex. Daily growth rate (DGR) as a function of the incubation time $\left(16^{\circ} \mathrm{C}\right.$, continuous darkness and without food). (A) November, January and March cruises with evidence of negative growth as a function of time, (B) July and September-October cruises with no evidence of negative growth as a function of time

intervals, we estimated an annual N. simplex standing stock biomass of about 387000 tons in the area of study (Table 5). The annual relative contributions to $N$. simplex total biomass production in the central and northern Gulf of California were dominated by the production of somatic growth $(46 \%)$, followed by the production of molts $(32 \%)$ and eggs $(22 \%)$.

\section{DISCUSSION}

\section{Vital rates}

All previous information about Nyctiphanes simplex biomass productivity, and therefore its vital rates, was deduced from preserved specimens (Lavaniegos 1995, GómezGutiérrez et al. 1996, De Silva-Dávila \& Palomares-García 1998, De SilvaDávila et al. 2002). The same approach was used to estimate biomass production for the other $3 \mathrm{Nyc}$ tiphanes species around the world (Lindley 1982, Ritz \& Hosie 1982, Hosie \& Ritz 1983, Barange \& Stuart 1991). Observations of the IMP of $3 N$. simplex specimens (Jerde \& Lasker 1966) and several direct IBP measurements (Gómez-Gutiérrez \& Robinson 2005) are all the vital rates previously reported for this species. Thus, our measurements of $N$. simplex vital rates (DGR and IMP) provide a new approach to estimate $N$. simplex biomass production rates in the Gulf of California more precisely. The key part was to estimate the vital rates under shipboard laboratory conditions, allowing us to demonstrate that: (1) A large proportion of the subtropical krill population does not grow or even shrinks regardless of season, but mean DGR consistently decreases as the animals grow larger, with larger mean DGR in January and November than in July. (2) The mean direct observed IMP varies little seasonally, though being slightly longer in winter (5 d) than in summer ( 3 d), and IMP calculated using the 1/MR method resulted in considerable longer IMP estimates (likely unrealistic: $>10 \mathrm{~d}$ at $>16^{\circ} \mathrm{C}$ ). (3) All females $>8 \mathrm{~mm}$ long produce at least 1 ovigerous sac each month (most likely 2 to 4 sacs), with an IBP likely ranging from 7 to $10 \mathrm{~d}$, implying that all females of the population are engaged in the monthly reproductive output, not only those females with ovigerous sacs at the time of collection (typically $<30 \%$ of the females collected); in the past, IBP was estimated to be $30 \mathrm{~d}$ (Lavaniegos 1995), thus only the proportion of females with an ovigerous sac used to be considered part of the female population contributing to reproduction. (4) Biomass and biomass production rate estimations obtained in the Gulf of California were comparatively lower than previous estimations obtained using only preserved animals. (5) We detected a considerably larger contribution of $N$. simplex molt and 


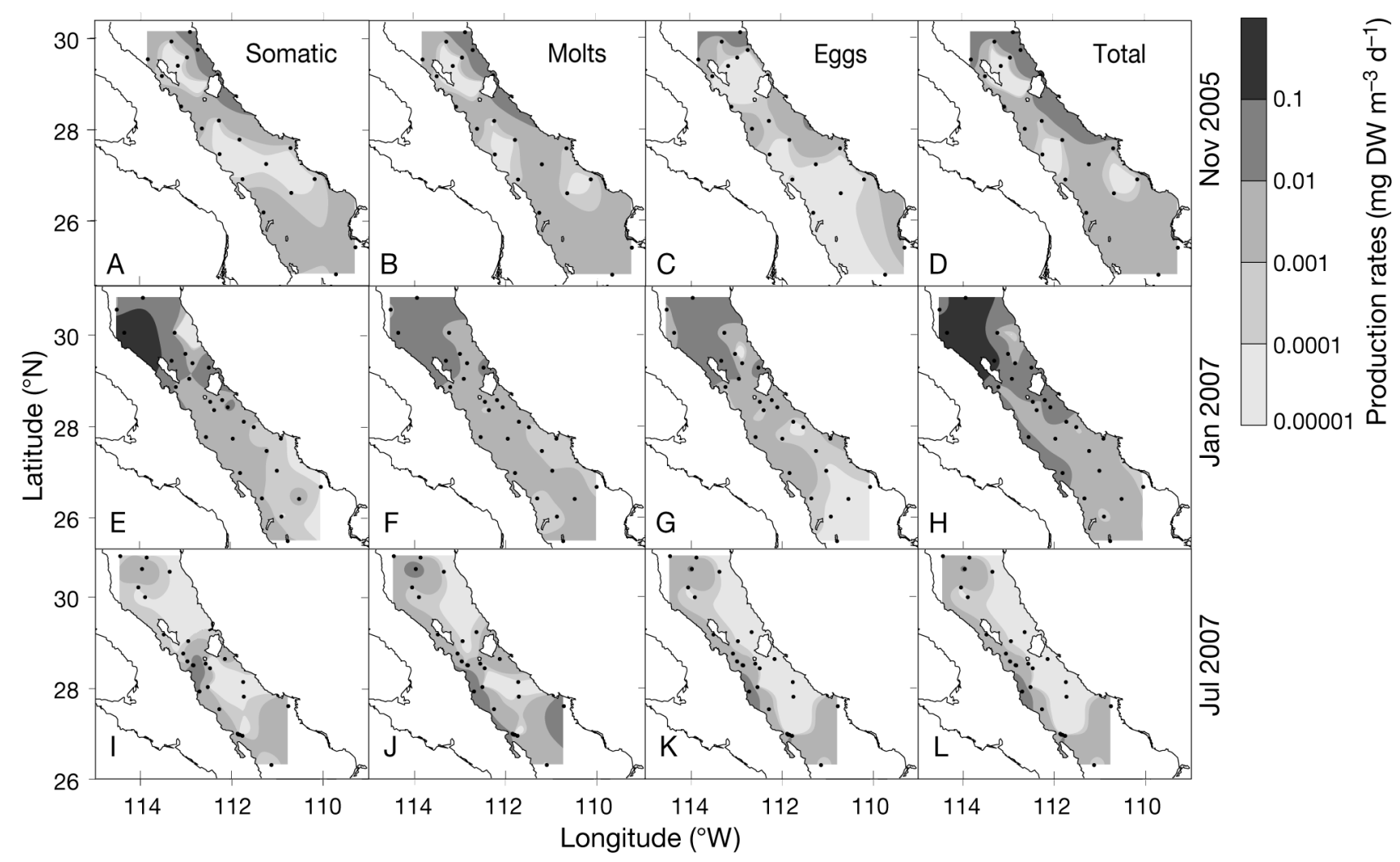

Fig. 7. Nyctiphanes simplex. Distribution of daily biomass production rates $\left(\mathrm{mg} \mathrm{DW} \mathrm{m}^{-3} \mathrm{~d}^{-1}\right.$ ) due to (A,E,I) somatic growth, $(\mathrm{B}, \mathrm{F}, \mathrm{J})$ molts, $(\mathrm{C}, \mathrm{G}, \mathrm{K})$ eggs, and $(\mathrm{D}, \mathrm{H}, \mathrm{L})$ total biomass production integrating these 3 components in the Gulf of California during (A-D) November 2005, (E-H) January 2007 and (I-L) July 2007

egg production rate to the total production rate (MPR: $32 \%$, EPR: $22 \%$ ) than previously thought (23 and $2 \%$, respectively) (Lavaniegos 1995), indicating that females can spawn throughout the year and that krill molt during their entire life span.

Nyctiphanes simplex had different IMP in each season in the Gulf of California ( $5 \mathrm{~d}$ for the cold season, $3 \mathrm{~d}$ for the warm season, and $4 \mathrm{~d}$ in the transition periods) (Fig. 5A). This seasonal IMP variability agrees with the general notion that a rise in temperature shortens krill IMP (Ikeda \& Dixon 1982, Pinchuk \& Hopcroft 2006, 2007, Kawaguchi et al. 2006, Shaw et al. 2010) and that during November intermediate temperatures prevail compared to January and July. Previous IMP estimates for $N$. simplex in California ranged from 5 to $7 \mathrm{~d}$ (Jerde \& Lasker 1966). We show that directly observed IMP ranges from 2 to $8 \mathrm{~d}$, and those estimated with the 1/MR method ranged from 4 to $60 \mathrm{~d}$ (Table 1). However, as observed in other euphausiid species (Tarling et al. 2006), the IMP of $N$. simplex ovigerous females must be longer than the IBP due to the unlikely event of molting before releasing the embryos from the ovigerous sac. About $22 \%$ of all ovigerous females carry a metanauplius embryo and have Stage III gonads simultaneously (Gómez-Gutiérrez et al. 2010b). Thus, at least this proportion of females likely spawns almost immediately after the embryos are released (IBP $=6$ to $8 \mathrm{~d}$ ). The remaining females likely have a longer IBP (9 to 49 d) (Gómez-Gutiérrez et al. 2010b). Therefore, females should have a longer IMP than the time required for the metanauplius embryos to leave the ovigerous sac and start their free-swimming planktonic phase. Thus, to estimate the IMP of the females collected in the wild, we assumed that at least $22 \%$ of the females collected with the bongo net had an average IMP of $6 \mathrm{~d}$, while the rest of the females in the population had an average IMP of 10 d (Gómez-Gutiérrez et al. 2010b).

Euphausiids are ectothermal organisms, therefore the energy cost to maintain homeostasis is likely high, particularly when the organisms are exposed to unfavorable environmental conditions. During July, the combined effect of increased water temperature above the thermocline (mean temperature in the upper $100 \mathrm{~m}: 21^{\circ} \mathrm{C}$ ), relatively shallow oxygen mini- 

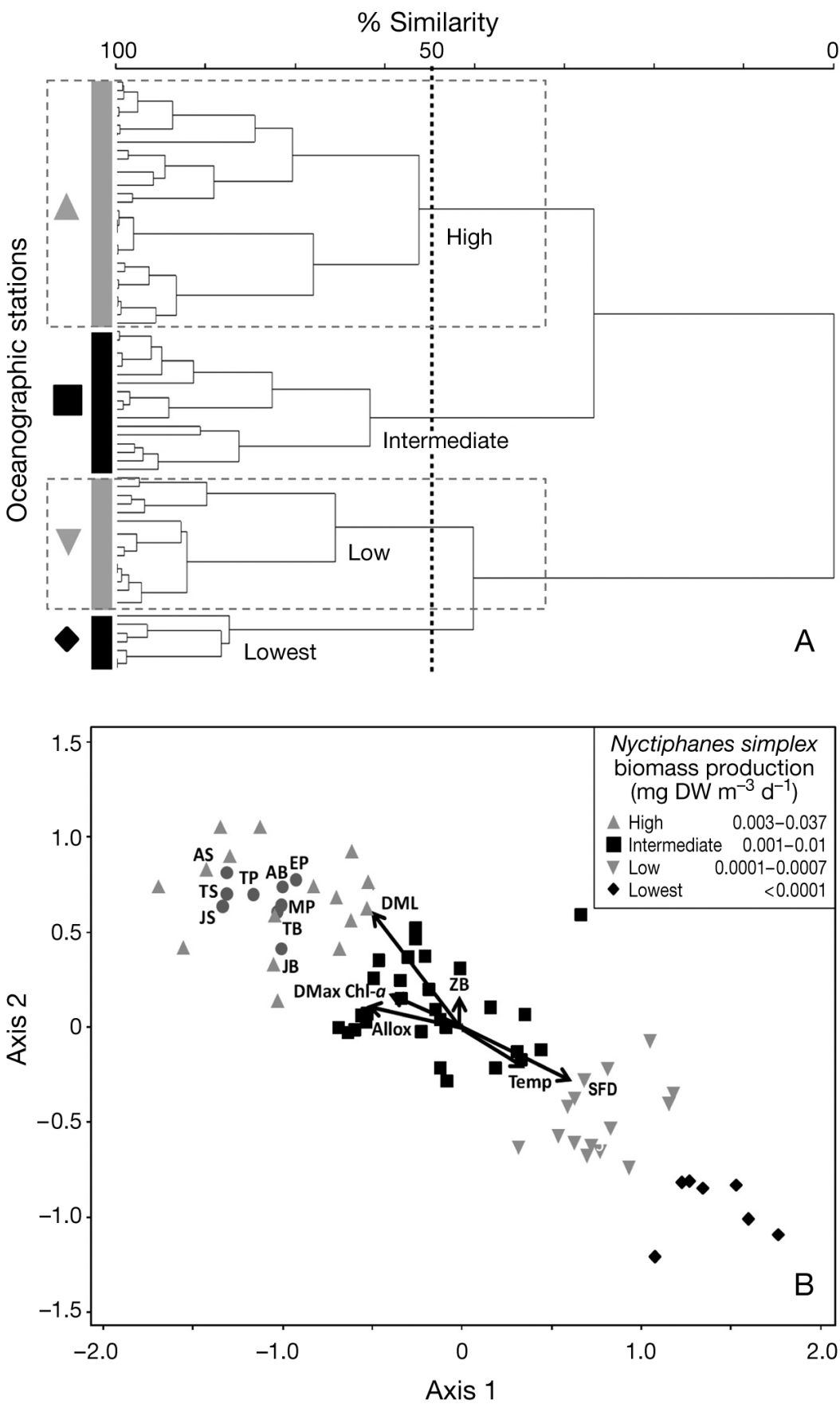

Fig. 8. (A) Bray-Curtis cluster analysis by oceanographic station. (B) Nonmetric multi-dimensional scaling of Nyctiphanes simplex biomass and biomass production as a function of 12 environmental gradients. The ordination was oriented to maximize the variability within groups defined by the BrayCurtis cluster analysis (high, intermediate, low, and lowest biomass and production rates). N. simplex variables: JB: juvenile biomass, AB: adult biomass, TB: total biomass (adults, juveniles, body growth, molts and eggs), JS: juvenile somatic growth production, AS: adult somatic growth production, TS: total somatic growth production, EP: egg production, MP: molt production, TP: total production. Environmental variables: ZB: zooplankton biomass, DML: depth of the mixed layer, SFD: seafloor depth at sampling station, Allox: alloxanthin accessory pigment concentration, Temp: temperature, DMax Chl-a: depth of peak maximum chl a concentration mum zone, and apparent seasonal decline in chl a concentration (20 mg chl a $\mathrm{m}^{-2}$ ) (Tremblay et al. 2010) had an overall negative effect on Nyctiphanes simplex somatic growth (GI and DGR), MPR, and EPR. Higher N. simplex biomass and biomass productivity rates were estimated during January (mean SST: $15^{\circ} \mathrm{C}$, deep oxygen minimum zone, and high mean chl a concentration: $55.6 \mathrm{mg} \mathrm{m}^{-2}$ ) than during November and July (with higher SST, shallower oxygen minimum zones, and lower chl a concentrations) (Fig. 8, Table 5). Euphausiids have evolved several physiological mechanisms to survive periods of low food availability or unfavorable environmental conditions (Marinovic \& Mangel 1999). Subarctic euphausiids accumulate lipids during periods of food abundance, and after these are metabolized, the euphausiids also have the ability to shrink as a strategy to decrease metabolic rates (Kawaguchi et al. 2006, Pinchuk \& Hopcroft 2007, Shaw et al. 2010). Although the Gulf of California is one of the regions with the highest seasonal variation of SST in the North Pacific Ocean $\left(6\right.$ to $\left.8^{\circ} \mathrm{C}\right)$, higher than the variation of SST along the west coast of Baja California $\left(\sim 4^{\circ} \mathrm{C}\right)$ (Wyrtki 1965, Knudsen et al. 1996), the seasonal $N$. simplex biomass and productivity changes were comparatively less pronounced than those estimated along the west coast of Baja California (Lavaniegos 1995, Gómez-Gutiérrez et al. 1996). We detected a significant proportion of the $N$. simplex population that did not grow or that even shrank in successive molts regardless of the season, likely as a direct response to local trophic conditions. This phenomenon of arrested growth or decreasing body size must also occur along the west coast of the Baja California Peninsula, thus previous growth rates may have been slightly overestimated. During July, the percentage of euphausiids with negative growth rate was higher than in November and January (when EPR peaked). This trend suggests that seasonal changes in stratification and depth of 
Table 3. Non-metric multi-dimensional scaling for the biomass and biomass production rate of Nyctiphanes simplex showing the Pearson-Kendall correlation (R) for the association among ordination distances and distances of the original $\mathrm{n}$-dimensional space for the available environmental variables. Bold: significant values $(p<0.05)$. Coefficients of determination are $r^{2}=0.718$ (Axis 1) and $\mathrm{r}^{2}=0.026$ (Axis 2)

\begin{tabular}{|lrr|}
\hline Environmental variable (units) & Axis 1 & Axis 2 \\
& $\mathrm{R}$ & $\mathrm{R}$ \\
\hline Oxygen minimum zone depth $(\mathrm{m})$ & $\mathbf{- 0 . 0 5 3}$ & $\mathbf{- 0 . 0 2 0}$ \\
Mean oxygen saturation from 0 to $75 \mathrm{~m}$ depth $(\%)$ & $\mathbf{0 . 0 4 1}$ & 0.079 \\
Zooplankton biomass $\left(\mathrm{ml} \mathrm{m}^{-3}\right)$ & $\mathbf{0 . 0 3 8}$ & -0.218 \\
Zeaxanthin accessory pigment concentration $\left(\mathrm{mg} \mathrm{m}^{-2}\right)$ & $\mathbf{0 . 0 0 3}$ & -0.103 \\
Integrated chl a concentration $\left(\mathrm{mg} \mathrm{m}^{-2}\right)$ & 0.136 & $\mathbf{0 . 0 4 4}$ \\
Column mixed layer depth $(\mathrm{m})$ & 0.239 & -0.087 \\
Sampling station seafloor depth $(\mathrm{m})$ & -0.227 & -0.155 \\
Alloxanthin accessory pigment concentration $\left(\mathrm{mg} \mathrm{m}^{-2}\right)$ & 0.201 & 0.218 \\
Depth of maximum chl a concentration $(\mathrm{m})$ & 0.191 & 0.128 \\
Mean temperature from 0 to $100 \mathrm{~m}$ depth $\left({ }^{\circ} \mathrm{C}\right)$ & -0.186 & -0.104 \\
Fucoxanthin accessory pigment concentration $\left(\mathrm{mg} \mathrm{m}^{-2}\right)$ & 0.144 & 0.084 \\
Chl $b$ accessory pigment concentration $\left(\mathrm{mg} \mathrm{m}^{-2}\right)$ & 0.107 & 0.105 \\
\hline
\end{tabular}

Table 4. Multi-response permutation procedure results for the comparison of Nyctiphanes simplex biomass and biomass production rates and environmental conditions by region (GC: Gulf of California), season and habitat (neritic: $<200 \mathrm{~m}$ depth, offshore: $>200 \mathrm{~m}$ depth). T: separation between groups determined by the Pearson type III distribution (the more negative $T$ is, the stronger the separation). $A$ : is the chance-corrected within-group agreement; $A=1$ if all items are identical within groups (delta $=0$, where delta is the weighted mean within group distance), $A=0$ if heterogeneity within groups is as expected by chance, and $A<0$ if heterogeneity within groups is higher than expected by chance (McCune et al. 2002)

\begin{tabular}{lrrr|}
\hline $\begin{array}{l}\text { Grouped stations }{ }^{\mathrm{a}} \text { tested } \\
\text { for the following hypotheses }\end{array}$ & $T$ & \multicolumn{1}{c}{$A$} & $\mathrm{p}$ \\
\hline Northern GC vs. Midriff vs. Central GC & -2.004 & 0.030 & 0.040 \\
Northern GC vs. Midriff + Central GC & -2.975 & 0.031 & 0.019 \\
Northern GC + Midriff vs. Central GC & 0.603 & 0.000 & 0.363 \\
November 2005 vs. January 2007 vs. July 2007 & 0.160 & -0.002 & 0.470 \\
Neritic vs. oceanic habitat & -3.860 & 0.039 & 0.008 \\
Neritic habitat vs. oceanic habitat & -3.860 & 0.039 & 0.008 \\
a No. of stations per group - northern GC: 13, Midriff: 21, central GC: 39, \\
November: 23, January: 27, July: 23, neritic: 34, offshore: 39
\end{tabular}

the mixed layer alter $N$. simplex physiology and hence its production rates, which is reflected in a substantial decrease in abundance during the summer, as previously observed (Brinton \& Townsend 1980, Lavaniegos et al. 1989). N. simplex likely have the ability to shrink or not grow as a physiological strategy to cope with lower food concentrations, higher temperatures, and relatively lower oxygen concentrations.

Nyctiphanes simplex is the second subtropical krill species that has been observed to shrink; the process was first reported in N. australis (Hosie \& Ritz 1989). This physiological capability to shrink seems to be an inherent characteristic of all species of the order Euphausiacea. The somatic shrinkage response was initially attributed to the effect of starvation (Hosie \& Ritz 1989, Iguchi \& Ikeda 1995), but even when food supplies are abundant, krill can shrink when exposed to higher temperatures (Buchholz 1985, Marinovic \& Mangel 1999), when EPR is high or highly frequent, or when sexual organs of females regress after the reproductive season (Tarling et al. 2006, Feinberg et al. 2007, Brown et al. 2010). The proportion of individuals that did not grow or that shrank is relatively high in Euphausia pacifica populations (Shaw et al. 2010) similar to what we observed in N. simplex. Shrinking in $N$. simplex females during January and November was likely associated with higher reproductive rates, while female shrinking during July was likely associated with in situ temperature increases and lower chl a concentrations. However, at times, juveniles and males also stop growing or shrink throughout the year. We suggest that multiple in situ environmental conditions are affecting DGR and modulating the productivity rates. The egg production of $N$. simplex has been recently conceptualized in more detail based on the observation and laboratory incubations of females (GómezGutiérrez \& Robinson 2005), observation of the vertical distribution of females in reproductive phase (Gómez-Gutiérrez et al. 2010a), and observation of their gonad cycle using histological techniques (Gómez-Gutiérrez et al. 2010b). Now it is clear that $N$. simplex females are capable of spawning 4 or 5 times per gonad cycle and have synchronous gonad development within groups (partial spawning strategy). These studies allowed us to understand the magnitude of the vital rates and the proportion of the population engaged in growth, molting and egg production processes-data that are required to estimate total biomass production rates. Reproduction in N. simplex females and males requires a significantly larger proportion of energy than previously thought, with females having longer IMP than males. 


\section{Seasonal variability of biomass and biomass production rates as a function of environmental conditions}

The Bray-Curtis cluster, NMDS, and MRPP multivariate statistical analyses demonstrated that, contrary to our expectations, biomass and biomass production was not seasonally segregated into periods with different magnitude. Nyctiphanes simplex population in the Gulf of California reaches its higher biomass and production rates in different regions (mostly concentrated in regions $<100 \mathrm{~m}$ depth) of the Gulf at each oceanographic cruise. The Midriff Archipelago region and the northern Gulf had consistently higher biomass and biomass production rates than the central Gulf. It was clear that a latitudinal cline (gradient) in biomass and productivity occurred in January and November, while a longitudinal gradient was associated with regions of higher phytoplankton biomass in July, indicated by high chl a concentrations and relatively lower temperatures. The Midriff Archipelago region is the coldest region in the Gulf because year-round upwelling conditions resulting from intense tidal currents and upwelling processes forced by winds occur there (Paden et al. 1991, López et al. 2006, Sánchez-Velasco et al. 2009). In the northern Gulf, the tidal mixing combined with the residual circulation of the northern Gulf (Santamaría-del-Angel et al. 1994, Hidalgo-Gonzalez \& Alvarez-Borrego 2004) result in high biomass production of $N$. simplex. The predominant circulation in the Gulf is anticyclonic during the winter when the water current flows along the east coast toward the equator. Overall, this circulation pattern causes a decrease in SST and northeast winds (by 8 to $12 \mathrm{~m}$ $\mathrm{s}^{-1}$ ) that generate upwelling events along the mainland coast (Douglas et al. 1993, Sánchez-Velasco et al. 2009, Marinone 2012). High concentrations of $\mathrm{chl} a$ and relatively low temperatures during January and November compared to July were evident around the Midriff Archipelago region. This anticyclonic circulation promoted higher $N$. simplex vital rates, biomass, and biomass production rates, especially north of Tiburón Island and South of Ángel de la Guarda Island. In July, the Gulf changes to a cyclonic circulation with a predominant poleward current flow along the western coast of the Gulf. This shift increases the SST and stratification that-combined with relatively weak winds with a southeast direction $\left(5 \mathrm{~m} \mathrm{~s}^{-1}\right)$ - cause weak and perhaps intermittent upwelling events along the west coast of the Gulf (Douglas et al. 1993, Sánchez-Velasco et al. 2009, Marinone 2012). Under these oceanographic and climatic conditions, $N$. simplex attained relatively high biomass along the west coast of the Gulf, but its biomass production rates were moderate in the rest of the study area, with relatively higher temperatures and lower chl a concentrations. A recent 3D numerical model of particle (plankton) connectivity in the Gulf of California predicts that high dispersion occurs from the mainland coastal areas in the central and southern part of the Gulf of California to the rest of the Gulf due to strong seasonal currents (large connectivity) (Marinone 2012). High particle retention

Table 5. Nyctiphanes simplex. Estimated mean juvenile and adult biomass and total biomass production rates on the basis of the estimated habitat area per $50 \mathrm{~m}$ seafloor depth intervals in the northern and central Gulf of California (see 'Materials and Methods: Annual population biomass production'). N: no. of stations. Climatic seasons - transition: June and November (60 d), cold: December to May (182 d), warm: July to October (123 d); ND = no data available

\begin{tabular}{|c|c|c|c|c|c|c|c|c|c|c|c|c|}
\hline $\begin{array}{l}\text { Depth } \\
\text { (m) }\end{array}$ & $\mathrm{N}$ & $\begin{array}{l}\text { Area of study } \\
\left(\mathrm{km}^{2}\right)(\%)\end{array}$ & \multicolumn{3}{|c|}{$\begin{array}{l}\text { Mean total biomass } \\
\left(\mathrm{mg} \mathrm{DW} \mathrm{m}^{-3}\right)\end{array}$} & \multicolumn{3}{|c|}{$\begin{array}{l}\text { Seasonal biomass } \\
\left(\mathrm{mg} \mathrm{DW} \mathrm{m}^{-3}\right)\end{array}$} & \multicolumn{2}{|c|}{$\begin{array}{cc}\text { Annual biomass } \\
\text { (mg DW } \\
\left.\mathrm{m}^{-3}\right) & (\mathrm{mg} \mathrm{DW} \\
\left.\mathrm{m}^{-2}\right)\end{array}$} & \multicolumn{2}{|c|}{$\begin{array}{l}\text { Regional biomass } \\
\text { (tons DW }(\%) \\
\text { area }^{-1} \text { ) }\end{array}$} \\
\hline \multicolumn{13}{|c|}{ Mean biomass } \\
\hline $0-50$ & 3 & $27532 \quad 17.4$ & 1.54 & ND & ND & 92.42 & ND & ND & 92.42 & 6.16 & 169633 & 43.8 \\
\hline $50-100$ & 5 & 157619.9 & 1.56 & 1.56 & 0.00 & 93.33 & 284.57 & 0.00 & 377.90 & 6.30 & 99265 & 25.6 \\
\hline $100-150$ & 9 & $11203 \quad 7.1$ & 0.54 & 1.58 & 1.65 & 32.13 & 287.57 & 203.23 & 522.94 & 4.55 & 50941 & 13.2 \\
\hline $150-200$ & 8 & $7253 \quad 4.6$ & 0.15 & 2.56 & 0.35 & 8.68 & 466.01 & 43.27 & 517.95 & 3.14 & 22767 & 5.9 \\
\hline$>200$ & 44 & 9681161.1 & 0.10 & 0.30 & 0.26 & 6.20 & 53.78 & 32.16 & 92.13 & 0.46 & 44598 & 11.5 \\
\hline Total & 69 & & 3.9 & 6.0 & 2.3 & 232.8 & 1091.9 & 278.7 & 1603.3 & 20.6 & 387205 & \\
\hline \multicolumn{13}{|c|}{ Total biomass production rate } \\
\hline $0-50$ & 3 & $27532 \quad 17.4$ & 0.0433 & 0.0000 & 0.0000 & 2.60 & 0.00 & 0.00 & 2.60 & 0.130 & 3578 & 28.7 \\
\hline $50-100$ & 5 & 157619.9 & 0.0483 & 0.0636 & 0.0000 & 2.90 & 11.58 & 0.00 & 14.48 & 0.223 & 3511 & 28.1 \\
\hline $100-150$ & 9 & $11203 \quad 7.1$ & 0.0148 & 0.1551 & 0.0454 & 0.89 & 28.23 & 5.59 & 34.70 & 0.302 & 3381 & 27.1 \\
\hline $150-200$ & 8 & $7253 \quad 4.6$ & 0.0044 & 0.0838 & 0.0108 & 0.26 & 15.25 & 1.33 & 16.84 & 0.102 & 740 & 5.9 \\
\hline$>200$ & 44 & 9681161.1 & 0.0036 & 0.0066 & 0.0098 & 0.21 & 1.20 & 1.21 & 2.62 & 0.013 & 1270 & 10.2 \\
\hline Total & 69 & & 0.11 & 0.31 & 0.07 & 6.86 & 56.25 & 8.13 & 71.24 & 0.77 & 12480 & \\
\hline
\end{tabular}


occurs in the northern Gulf of California during 9 to 12 months of the year due to a seasonal eddy-like circulation pattern, and in the southern Gulf on the peninsular side because of the weak seasonal currents that potentially promote large auto-recruitment (low connectivity) (Marinone 2012). This explains why high biomass regions of $N$. simplex change seasonally, i.e. the changes are partially caused by regional connectivity features that are controlled by current circulation.

The seasonal variability in regions with high $N_{y c t i-}$ phanes simplex biomass and biomass productivity rates in the Gulf of California is closely related with regional connectivity among regions that vary seasonally (Marinone 2012). This is relevant because advection processes affects both the regional grazing impact on lower trophic levels and the available prey biomass for krill predators. In a hypothetical scenario, a $N$. simplex individual of $6 \mathrm{~mm}$ total length in January (roughly 2 mo old) could survive for about 8 mo (considered so far as average longevity; Lavaniegos 1992) and could potentially molt about 45 times (molt biomass: $\sim 10.6 \mathrm{mg} \mathrm{DW}$ ind $^{-1}$ ) equivalent to about 10 times the euphausiid body weight. Our estimation of the \%DW of the molt-to-animal in relation to the total weight of the animal (5.7\%) was virtually the same as the percentage assumed by Lavaniegos (1995) obtained from N. australis (Hosie \& Ritz 1983). This similarity indicates a possible constant relationship between molt and animal DW in the genus Nyctiphanes and likely for all the euphausiids worldwide. However, Jerde \& Lasker (1966) estimated that $N$. simplex relative molt weight varied between 11 and $15.7 \%$ of the total weight $(\mathrm{n}=3)$. The molts produced by $N$. simplex are consumed by exuviotrophic ciliates (Landers et al. 2006, Gómez-Gutiérrez et al. 2010c), which is aided by bacterial degradation that helps to soften the molts while they sink through the water column. Virtually all fresh molts observed on board had numerous exuviotrophic ciliates swimming on the in the inner space of the released exoskeleton. The sinking rate of intact Euphausia pacifica molts in seawater at $10^{\circ} \mathrm{C}$ and salinity of 33 is $0.33 \mathrm{~m} \mathrm{~min}^{-1}$ off Californian coast (Lasker 1966). Thus, assuming similar sinking rates for $N$. simplex, the molts produced in the upper $100 \mathrm{~m}$ of the water column can stay in the upper $400 \mathrm{~m}$ (where they contribute to the detritus biomass and marine snow standing stock) for $\sim 1 \mathrm{~d}$. Because crustaceans dominate the zooplankton community structure (70 to $90 \%$ ) in the Gulf of California (Brinton et al. 1986), the contribution of their molts should be a significant portion of the carbon reservoir in the epipelagic ecosystem.
The NMDS was useful to detect the areas with (1) high biomass production rates, typically located near the shore ( $<100 \mathrm{~m}$ seafloor depth) and decreasing offshore, and (2) higher biomass and biomass production rates, which were inversely associated with the temperature in each season. Surprisingly, we found a significant association of high Nyctiphanes simplex biomass and production rates with the concentration of alloxanthin. Alloxanthin is a major carotenoid accessory pigment of microalgae of the division Cryptophyta. We propose the hypothesis that the association of high biomass and production rates of $N$. simplex that occurs in regions with relatively high alloxanthin concentrations is probably linked to euphausiid capability to feed on the relatively small (8 to $60 \mu \mathrm{m}$ ) cryptophytic microalgae. However, the nutritional effect and confirmation of higher growth, MPR, and/or EPR with a diet of cryptophytes must be tested experimentally in the future. Another possibility is that cryptophytes tend to be in endosymbiotic association (kleptoplasty) with the ciliate Miryonecta rubra, which sometimes can produce massive proliferations in the Gulf of California (Gárate-Lizárraga et al. 2002, Hernández-Becerril et al. 2007, 2008, López-Cortés et al. 2008). This ciliate could be a potential significant food source for $N$. simplex, as shown for other zooplankton species (Henrik et al. 2000, López-Cortés et al. 2008).

\section{Nyctiphanes simplex biomass and biomass produc- tion rates in northwestern Mexican waters}

Mean juvenile and adult abundance of Nyctiphanes simplex recorded in this study (November 2005: 525 ind. $1000 \mathrm{~m}^{-3}$; January 2007: 710 ind. $1000 \mathrm{~m}^{-3}$; and July 2007: 524 ind. $1000 \mathrm{~m}^{-3}$ ) were similar to those abundances reported in February 1957 (402 ind. $1000 \mathrm{~m}^{-3}$ ), but considerably lower than in April (2311 ind. $1000 \mathrm{~m}^{-3}$ ), June (11373 ind. 1000 $\mathrm{m}^{-3}$ ), and August (2698 ind. $1000 \mathrm{~m}^{-3}$ ) 1957 (Brinton \& Townsend 1980). Thus, because abundance was almost 7 times higher in 1957 (mean 4196 ind. 1000 $\mathrm{m}^{-3}$ ) than in 2005 and 2007 (617 ind. $1000 \mathrm{~m}^{-3}$ ), estimated annual biomass and biomass production rates (assuming similar mean vital rates) would also be higher in 1957 than in 2005 and 2007. However, it is unclear if such abundance differences were observed because 1957 (El Niño) environmental conditions were more favorable for $N$. simplex, because there were decadal regime differences between the 1950s and 2000s, or simply because we did not sample during the season with apparently larger $N$. sim- 
plex abundance (April to June). However, large differences between June 1957 and July 2007 with similar seasonal conditions suggest that indeed 1957 had higher abundances than 2007. Because different methodologies and development phases (larvae, juvenile and adults) were used in previous estimations of $N$. simplex biomass production rates, e.g. using only preserved krill samples (Lavaniegos 1995, Gómez-Gutiérrez et al. 1996, De Silva-Dávila \& Palomares-García 1998, De Silva-Dávila et al. 2002), it is also difficult to compare biomass production on both sides of the Baja California peninsula. A table summarizing all previous $N$. simplex body growth estimations is shown in De Silva-Dávila et al. (2002). In the Gulf of California, we estimated a total annual juvenile and adult biomass production rate (body growth, MPR, and EPR) of $71 \mathrm{mg} \mathrm{DW} \mathrm{m}{ }^{-3} \mathrm{yr}^{-1}$. This estimate is considerably smaller than the annual larval somatic body growth production of $N$. simplex in Bahía de La Paz (196 mg DW m ${ }^{-3} \mathrm{yr}^{-1}$ ) (De SilvaDávila \& Palomares-García 1998), where individuals $<6 \mathrm{~mm}$ total length predominate in the daytime samples, and larger than the annual juvenile and adult somatic body growth production recorded on the Bahía Magdalena continental shelf $\left(273 \mathrm{mg} \mathrm{DW} \mathrm{m}^{-2}\right.$ $\mathrm{yr}^{-1}=5 \mathrm{mg} \mathrm{DW} \mathrm{m}^{-3} \mathrm{yr}^{-1}$ ) (Gómez-Gutiérrez et al. 1996). In Vizcaino Bay, Lavaniegos (1995) reported an annual $N$. simplex total production of $1736 \mathrm{mg}$ DW m ${ }^{-2} \mathrm{yr}^{-1}$. The mean sampling depth of this study was approximately $61 \mathrm{~m}$, thus $N$. simplex total production was estimated to be $29 \mathrm{mg} \mathrm{DW} \mathrm{m}{ }^{-3} \mathrm{yr}^{-1}$. In the Gulf of California, the proportion of egg production in relation to total production was about 10 times higher than in Vizcaino Bay. This comparison suggests that the vital rate information is a more precise way to determine how N. simplex uses its energy to produce its individual and population biomass. Considering that the vital rates of $N$. simplex must be relatively similar in magnitude (although it is evident that temporal or geographical differences must be expected) on both sides of the Baja peninsula, higher EPR should also exist in Vizcaino Bay where the egg production calculations would include the entire female population instead of only the proportion of ovigerous females collected during the oceanographic cruise. The relative contributions of somatic growth $(46 \%)$, MPR $(32 \%)$, and EPR $(22 \%)$ to N. simplex biomass production in the Gulf of California were significantly different from those estimated in Vizcaino Bay (somatic growth: $74.7 \%$, MPR: $23.4 \%$, EPR: $1.9 \%$ ) (Lavaniegos 1995) and $N$. australis (somatic growth: $74.2 \%$, MPR: $24.3 \%$, EPR: $1.3 \%$ ) (Ritz \& Hosie 1982, Hosie \& Ritz 1983). The estima- tions for Vizcaino Bay and N. australis were virtually identical because they assumed the same vital rates and continuous euphausiid growth throughout the life cycle, neglecting no growth or shrinking periods that occur under unfavorable climatic and/or feeding conditions (Shaw et al. 2010, this study).

Although previous studies have estimated mean daily or annual Nyctiphanes simplex production rates, no one attempted to provide an estimation of its instantaneous biomass standing stock and overall biomass production. This extrapolation can be useful to explore the trophic role of $N$. simplex and to estimate the available standing stock available to top predators, which support regional eco-touristic activities. N. simplex habitat volume in the Gulf of California occupies mostly the area of the continental shelf $<200 \mathrm{~m}$ in depth (Brinton \& Townsend 1980, Lavaniegos 1996, Gómez-Gutiérrez et al. 2010a, Tremblay et al. 2010). Thus, $N$. simplex is mostly distributed in the neritic habitat that comprises only about $27 \%$ of the epipelagic habitat in the central and northern Gulf of California. We demonstrate that the $N$. simplex population concentrates about $69 \%$ of its total biomass and about $57 \%$ of its total biomass production rates along the neritic region (seafloor depths $<100 \mathrm{~m}$ ). The neritic affinity of $N$. simplex can influence the distribution patterns of their predators like the fin whale Balaenoptera physalus and the blue whale $B$. musculus. Electronic tagging indicates that fin whales in the Gulf of California regularly move distances up to $400 \mathrm{~km}$ to locate euphausiid swarms and forage in localized areas with relatively high densities of prey (Urbán et al. 2005, Ladrón de Guevara et al. 2008), and blue whales migrate annually from Californian waters to the Gulf of California in order to feed on dense krill swarms (Gendron 1992). The consumption rates and population sizes of these and other predators of euphausiids (e.g. juvenile jumbo squid Dosidicus gigas, myctophids, whale sharks) and parasitoid ciliates are still unknown (GómezGutiérrez et al. 2010c, 2012). Although N. simplex experience high predation pressure, this species may maintain high population replacement rates because they reproduce throughout the year, have a life span of nearly $1 \mathrm{yr}$ and high biomass production rates. That combination of traits ensures the re-colonization of habitat lost during the months of greatest environmental stress (summer and autumn). However, top predators must search for areas with high concentrations of N. simplex and other zooplankton species that change in time and space closely associated with water current circulation and connectivity among regions in the Gulf of California (Marinone 2012). 
Acknowledgements. J.G.G. dedicates this publication to Marnie Knight (Scripps Institute of Oceanography) for her invaluable friendship, guidance, and mentoring since 1990. She was an outstanding example of dedication on investigation of euphausiid larvae taxonomy, a kind person, and a dearest friend. We thank J. Del Angel-Rodríguez for his help in the estimation of study area using ImageJ software and his valuable help onboard. We also thank the crew, students (N. Tremblay, F. Domínguez, M. Aguilar, O. AnguloCampillo), and researchers that participated on the RV 'El Puma' for their cooperation in collecting acoustic and zooplankton samples. This work was funded by the Centro Interdisciplinario de Ciencias Marinas (Instituto Politécnico Nacional, SIP 2005-2010 research projects), Consejo Nacional de Ciencia y Tecnología (FOSEMARNAT-2004-01C01-144, SAGARPA S007-2005-1-11717), and Instituto de Ciencias del Mar y Limnología (UNAM, PAPIIT IN219502, IN210622). J.G.G. and C.J.R. are SNI fellows, and J.G.G. is supported by COFAA-IPN and EDI-IPN grants. We deeply thank 5 anonymous referees for the critical and insightful comments that significantly improved our manuscript.

\section{LITERATURE CITED}

Barange M, Stuart V (1991) Distribution patterns, abundance and population dynamics of the euphausiids $\mathrm{Nyc}$ tiphanes capensis and Euphausia hanseni in the northern Benguela upwelling system. Mar Biol 109:93-101

Brinton E, Townsend AW (1980) Euphausiids in the Gulf of California - the 1957 cruises. Calif Coop Ocean Fish Invest Rep 21:211-236

Brinton E, Fleminger A, Siegel DC (1986) The temperate planktonic biotas of the Gulf of California. Calif Coop Ocean Fish Invest Rep 27:228-266

Brown M, Kawaguchi S, Candy S, Virtue P (2010) Temperature effects on the growth and maturation of Antarctic krill (Euphausia superba). Deep-Sea Res II 57:672-682

Buchholz F (1985) Moult and growth in euphausiids. In: Siegfried WR, Condy P, Laws RM (eds) Antarctic nutrient cycles and food webs. Proc 4th SCAR Symp Antarct Biol. Springer, Berlin, p 339-345

> De Silva-Dávila R, Palomares-García R (1998) Unusual larval growth production of Nyctiphanes simplex in Bahía de La Paz, Baja California, Mexico. J Crustac Biol 18: 490-498

> De Silva-Dávila R, Palomares-García R, Martínez-López A, Carballido-Carranza MA (2002) Standing stock of Nyctiphanes simplex in the southern region of the California Current System. J Plankton Res 24:1057-1066

Douglas MW, Maddox RA, Howard K, Reyes S (1993) The Mexican monsoon. J Clim 6:1665-1667

Feinberg LR, Shaw CT, Peterson WT (2007) Long-term laboratory observations of Euphausia pacifica fecundity: a comparison of two geographic regions. Mar Ecol Prog Ser 341:141-152

Gárate-Lizárraga I, Band-Schmidt CJ, Cervantes-Duarte R, Escobedo-Urías D (2002) Mareas rojas de Mesodinium (Lohman) Hamburger y Buddenbrock en el Golfo de California (invierno de 1998). Hidrobiológica 12:15-20

Gárate-Lizárraga I, Band-Schmidt CJ, Grayeb del Alamo T (2008) Myrionecta, Gyrodinium and Katodinium bloom in Gulf of California. Harmful Algae News 37:6-7

Gendron D (1992) Population structure of daytime surface swarms of Nyctiphanes simplex (Crustacea: Euphausiacea) in the Gulf of California, México. Mar Ecol Prog
Ser 87:1-6

Gómez-Gutiérrez J, Robinson CJ (1997) Circadian biomass and abundance changes of five euphausiids along the west coast of Baja California Mexico, December 1993. Sci Mar 61:27-35

Gómez-Gutiérrez J, Robinson CJ (2005) Embryonic, early larval development time, hatching mechanism and interbrood period of the sac-spawning euphausiid Nyctiphanes simplex Hansen. J Plankton Res 27:279-295

Gómez-Gutiérrez J, Robinson CJ (2006) Tidal current transport of epibenthic swarms of the euphausiid Nyctiphanes simplex in a shallow subtropical bay in Baja California Sur, México. Mar Ecol Prog Ser 320:215-231

Gómez-Gutiérrez GJ, De Silva-Dávila R, Lavaniegos BE (1996) Growth production of the euphausiid Nyctiphanes simplex on the coastal shelf of Magdalena Bay, Baja California Sur, Mexico. Mar Ecol Prog Ser 138:309-314

> Gómez-Gutiérrez J, Feinberg LR, Shaw TC, Peterson WT (2007) Interannual and geographical variability of the brood size of the euphausiids Euphausia pacifica and Thysanoessa spinifera along the Oregon coast (19992004). Deep-Sea Res I 54:2145-2169

> Gómez-Gutiérrez J, Tremblay N, Martínez-Gómez S, Robinson CJ, Del Ángel-Rodríguez J, Rodríguez-Jaramillo C, Zavala-Hernández C (2010a) Biology of the subtropical sac-spawning euphausiid Nyctiphanes simplex in the northwestern seas of Mexico: vertical and horizontal distribution patterns and seasonal variability of brood size. Deep-Sea Res II 57(7-8):606-615

Gómez-Gutiérrez J, Rodríguez-Jaramillo C, Del ÁngelRodríguez J, Robinson CJ, Zavala-Hernández C, Tremblay N, Martínez-Gómez S (2010b) Biology of the subtropical sac-spawning euphausiid Nyctiphanes simplex in the northwestern seas of Mexico: interbrood period, gonad development and lipid content. Deep-Sea Res II 57(7-8):616-630

> Gómez-Gutiérrez J, Robinson CJ, Kawaguchi S, Nicol S (2010c) Parasite diversity of Nyctiphanes simplex and Nematoscelis difficilis (Crustacea: Euphausiacea) along the Northwestern coast of Mexico. Dis Aquat Org 88(3):249-266

> Gómez-Gutiérrez J, Strüder-Kypke M, Lynn D, Shaw TC and others (2012) Pseudocollinia brintoni n. gen. n. sp. (Apostomatida: Colliniidae) a parasitoid ciliate infecting the euphausiid Nyctiphanes simplex off Baja California, Mexico. Dis Aquat Org 99:57-78

Henrik L, Jefferson TT, Torkel GN, Hansen BW (2000) On the trophic coupling between protists and copepods in arctic marine ecosystems. Mar Ecol Prog Ser 204:65-77

- Hernández-Becerril DU, Alonso-Rodríguez R, ÁlvarezGógora C, Barón-Campis SA and others (2007) Toxic and harmful marine phytoplankton and microalgae (HABs) in Mexican coasts. J Environ Sci Health Part A Toxic/ Hazard Subst Environ Eng 42(10):1349-1363

> Hidalgo-Gonzalez RM, Alvarez-Borrego S (2004) Total and new production in the Gulf of California estimated from ocean color data from the satellite sensor SeaWIFS. Deep-Sea Res II 51:739-752

> Hosie GW, Ritz DA (1983) Contribution of molting and eggs to secondary production in Nyctiphanes australis (Crustacea: Euphausiacea). Mar Biol 77:215-220

> Hosie GW, Ritz DA (1989) Body shrinkage in the subtropical euphausiid Nyctiphanes australis G.O. Sars. J Plankton Res 11:595-598

Iguchi N, Ikeda T (1995) Growth, metabolism and growth 
efficiency of a euphausiid crustacean Euphausia pacifica in the southern Japan Sea, as influenced by temperature. J Plankton Res 17:1757-1769

> Ikeda T, Dixon D (1982) Observations of moulting in Antarctic krill (Euphausia suberba Dana). Aust J Mar Freshw Res 33:71-76

Jerde CW, Lasker R (1966) Molting of euphausiid shrimps: shipboard observations. Limnol Oceanogr 11:120-124

Kanaeva IP, Pavlov VY (1976) Nekotorye voprosy biologii Nyctiphanes simplex Hansen. [Some aspects of the biology of Nyctiphanes simplex Hansen]. In: Nejman AA (ed) Makroplankton morej i okeanov [Macroplankton of seas and oceans], Vol 110. Pishchevaya Promyshlennost Moscow, p 90-94 (In Russian)

Kawaguchi S, Candy SG, King R, Naganobu M, Nicol S (2006) Modelling growth of Antarctic krill. I. Growth trends with sex, length, season and region. Mar Ecol Prog Ser 306:1-15

Kimmerer WJ (1987) The theory of secondary production calculation for continuously reproducing populations. Limnol Oceanogr 32:1-13

Knudsen P, Andersen OB, Knudsen T (1996) ATSR sea surface temperature data in a global analysis with TOPEX/ POSEIDON altimetry. Geophys Res Lett 23:821-824

> Ladrón de Guevara PP, Lavaniegos BE, Heckel G (2008) Fin whales (Balaenoptera physalus) foraging on daytime surface swarms of the euphausiid Nyctiphanes simplex in Ballenas Channel, Gulf of California, Mexico. J Mammal 89:559-566

Landers SC, Gómez-Gutiérrez J, Peterson WT (2006) Gymnodinioides pacifica, n. sp., an exuviotrophic ciliated protozoan (Ciliophora, Apostomatida) from euphausiids of the Northeastern Pacific. Eur J Protistol 42:97-106

Lasker R (1966) Feeding, growth, respiration, and carbon utilization of a euphausiid crustacean. J Fish Res Board Can 23:1291-1317

Lavaniegos EB (1992) Growth and larval development of Nyctiphanes simplex in laboratory conditions. Calif Coop Ocean Fish Invest Rep 33:162-171

> Lavaniegos EB (1995) Production of the euphausiid Nyctiphanes simplex in Bahia Vizcaíno western Baja California. J Crustac Biol 15:444-453

Lavaniegos BE (1996) Vertical distribution of euphausiid life stages in waters adjacent to Baja California. Fish Bull 94:300-312

Lavaniegos BE, Lara-Lara JR, Brinton E (1989) Effect of the 1982-83 El Niño event on the euphausiid populations of the Gulf of California. Calif Coop Ocean Fish Invest Rep 30:73-87

Lavin MF, Marinone SG (2003) An overview of the physical oceanography of the Gulf of California. In: Velasco Fuentes OU, Sheinbaum J, Ochoa J (eds) Nonlinear processes in geophysical fluid dynamics. Kluwer Academic, Dordrecht, p 173-204

- Lindley JA (1982) Population dynamics and production of euphausiids. III. Meganyctiphanes norvegica and Nyctiphanes couchi in the North Atlantic Ocean and the North Sea. Mar Biol 66:37-45

López M, Candela J, Argote ML (2006) Why does the Ballenas Channel have the coldest SST in the Gulf of California? Geophys Res Lett 33:L11603. doi:10.1029/2006 GL025908

López-Cortés DJ, Gárate-Lizárraga I, Bustillos-Guzmán JJ, Hernández-Sandoval F (2008) Blooms of Myrionecta rubra in Bahía de La Paz, Gulf of California, during early summer of 2005. Oceánides 23:1-10

Mantoura RFC, Repeta D (1997) Calibration methods for HPLC. In: Jeffrey SW, Mantoura RFC, Wright SW (eds) Phytoplankton pigments in oceanography: guidelines to modern methods. UNESCO Publ, Paris, p 407-428

Marinone SG (2012) Seasonal surface connectivity in the Gulf of California. Estuar Coast Shelf Sci 100:133-141

Marinovic B, Mangel M (1999) Krill can shrink as an ecological adaptation to temporarily unfavorable conditions. Ecol Lett 2:338-343

McCune B, Mefford MJ (1999) Multivariate analysis of ecological data. PC-ORD, CD v. 4.26 beta. MjM software. Gleneden Beach, OR. http://home.centurytel.net/ mjm/ pcordwin.htm

McCune B, Grace J, Urban D (2002) Analysis of ecological communities. MjM software designs. Gleneden Beach, OR

> Paden CA, Abbott MR, Winant CD (1991) Tidal and atmospheric forcing of the upper ocean in the Gulf of California. Part I: sea surface temperature variability. J Geophys Res 96(C10):18337-18359

Palomares-García R, Bustillos-Guzmán JJ, López-Cortés D (2006) Pigment-specific rates of phytoplankton growth and microzooplankton grazing in a subtropical lagoon. J Plankton Res 28:1217-1232

Pauly D, Christensen V, Walters CJ (2000) Ecopath, Ecosim and Ecospace as tools for evaluating ecosystem impacts of fisheries. ICES J Mar Sci 57:697-709

Pinchuk AI, Hopcroft RR (2006) Egg production and early development of Thysanoessa inermis and Euphausia pacifica (Crustacea: Euphausiacea) in the northern Gulf of Alaska. J Exp Mar Biol Ecol 332:206-215

Pinchuk AI, Hopcroft RR (2007) Seasonal variations in the growth rates of euphausiids (Thysanoessa inermis, $T$. spinifera, and Euphausia pacifica) from the northern Gulf of Alaska. Mar Biol 10:483-493

Ritz DA, Hosie GW (1982) Production of the euphausiid Nyctiphanes australis in Storm Bay, south-eastern Tasmania. Mar Biol 68:103-110

> Rosas-Luis R, Salinas-Zavala CA, Koch V, Del Monte Luna P, Morales-Zárate MV (2008) Importance of jumbo squid Dosidicus gigas (Orbigny, 1835) in the pelagic ecosystem of the central Gulf of California. Ecol Model 218:149-161

Sánchez-Velasco L, Lavín MF, Peguero-Icaza M, LéonChávez CA, Contreras-Catala F (2009) Seasonal changes in larval fish assemblages in a semi-enclosed sea (Gulf of California). Cont Shelf Res 29:1697-1710

> Santamaría-Del Angel E, Álvarez-Borrego S, Müller-Karger FE (1994) The 1982-1984 El Niño in the Gulf of California as seen in the coastal zone scanner imagery. J Geophys Res 99:7423-7431

Shaw CT, Peterson WT, Feinberg LR (2010) Growth of Euphausia pacifica in the upwelling zone off the Oregon coast. Deep-Sea Res II 57:584-593

Smith PE, Richardson S (1977) Standard techniques for pelagic fish egg and larvae survey. FAO Fish Tech Pap 175. FAO, Rome

> Tarling GA, Shreeve RS, Hirst AG, Atkinson A, Pond DW, Murphy EJ, Watkins JL (2006) Natural growth rates in Antarctic krill (Euphausia superba): I. Improving methodology and predicting intermolt period. Limnol Oceanogr 51:959-972

Tremblay N, Gómez-Gutiérrez J, Zenteno-Savín T, Robinson CJ, Sánchez-Velasco L (2010) Role of oxidative stress in seasonal and daily vertical migration of three species 
of krill in the Gulf of California. Limnol Oceanogr 55:2570-2584

Urbán RJ, Rojas-Bracho L, Guerrero-Ruiz M, JaramilloLegorreta A, Findley LT (2005) Cetacean diversity and conservation in the Gulf of California. In: Cartron JE, Ceballos G, Felger RS (eds) Biodiversity, ecosystems, and conservation in northern Mexico. Oxford University Press, New York, NY, p 276-297

Vidussi F, Claustre H, Bustillos-Guzmán J (1996) Determi-

Editorial responsibility: Marsh Youngbluth,

Fort Pierce, Florida, USA nation of chlorophylls and carotenoids of marine phytoplankton: separation of chlorophyll a from divinylchlorophyll $a$ and zeaxanthin from lutein. J Plankton Res 18:2377-2382

Winberg GG (1971) Methods for the estimation of production of aquatic animals. Academic Press, London

Wyrtki K (1965) The annual and semiannual variation of sea surface temperature in the North Pacific Ocean. Limnol Oceanogr 10:307-313

Submitted: October 10, 2010; Accepted: January 27, 2012 Proofs received from author(s): May 12, 2012 